\title{
Innovate to Survive: The Effect of Technology Competition on Corporate Bankruptcy
}

\author{
Assaf Eisdorfer $\quad$ Po-Hsuan Hsu*
}

August 2011

Forthcoming at Financial Management

This paper establishes a strong relation between technology competition and corporate bankruptcy. Using detailed firm-level patent data we show that: 1) the capability of firms to innovate predicts future bankruptcies better than the typical measures such as Z-score and credit rating, 2) technology-related bankruptcies are less sensitive to the business cycle and industry success, and 3) firms that go bankrupt as a result of technology competition experience larger declines in earnings and stock prices.

Keywords: Bankruptcy, Technology, Patents

JEL Classifications: G33, O33

We thank Bill Christie (the editor), an anonymous referee, Jerry Cao, Dhammika Dharmapala, JinChuan Duan, Fangjian Fu, Chinmoy Ghosh, Carmelo Giaccotto, Charles M. Jones, Roger Loh, WeiLing Song, Krishnamurthy Subramanian, Jerome Taillard, Bernard Yeung, and seminar participants at the University of Connecticut, the National University of Singapore, the Singapore Management University, the 2009 NTU IEFA Conference, the FMA 2009 Annual Meeting, and the 2010 CICF Conference for valuable comments and suggestions.

* Assaf Eisdorfer is an Associate Professor of Finance at the University of Connecticut, Storrs, CT 06269. Po-Hsuan Hsu is an Assistant Professor of Finance at the University of Hong Kong, Hong Kong, China. 
The finance literature has a long history of analyzing corporate bankruptcy. This includes development of bankruptcy prediction models, assessment of bankruptcy costs, and analysis of the association between bankruptcy and macroeconomic conditions. While many bankruptcy studies cover a large set of accounting- and finance-based data, no study has examined directly the influence of technology competition on bankruptcy. In this paper, we argue and find that the ongoing technology progress of firms contains important information with respect to the risk, costs, and pattern of bankruptcy.

As technology rapidly advances, firms have to operate in highly competitive environments full of gradual and radical innovations. These scenarios provide firms with an opportunity to become market leaders if they develop the most recent, updated, and well-adopted technologies. Yet, they also involve non-trivial operational risk if the firms lose in the technology race. That is, firms outperformed by their competitors in technology-intensive industries typically find it challenging to catch up, which could lead to a substantial bankruptcy risk. ${ }^{1}$

The patent system makes the relation between technology competition and bankruptcy even more direct. A patent assignee firm can sue competitors for infringement of its patents. Litigation may prohibit the defendant from performing any activities potentially related to that infringement. Should a court grant the plaintiff firm's request of injunction, some operations of the defendant could be shut down. This enforcement can result in severe financial distress for the defendant firm (see, e.g., Lanjouw and Lerner, 2001). Moreover, all other explicit and implicit costs arising in the

\footnotetext{
${ }^{1}$ A recent article in the Wall Street Journal observes: "Wary of emerging from the recession with obsolete products, big U.S. companies spent nearly as much on research and development in the dismal last quarter of 2008 as they did a year earlier,... Big R\&D spenders say they've learned from past downturns that they must invest through tough times if they hope to compete when the economy improves" (Scheck and Glader, April 6, 2009).
} 
patent litigation process can seriously deteriorate the financial status of the defendant (see Lerner, 1995; Hall 2004).

We propose a simple model to analyze the association between technology competition and bankruptcy. The model considers two firms competing over a new technology in a representative industry, and produces the effects of this competition on bankruptcy properties. The implications of the model are consistent with the economic intuition obtained from the literature, and prompt three primary hypotheses. The first hypothesis posits that the level of a firm's technology competitiveness predicts its likelihood to go bankrupt. The common bankruptcy prediction models rely primarily on financial ratios that reflect the current financial status and operating performance of the firm. These ratios, however, do not necessarily capture the status of the firm in the technology competition, which can be a dominant factor in the survival of the firm, especially in industries characterized by intensive technological innovations.

The second hypothesis addresses the relation between bankruptcy and macroeconomic conditions. Economic intuition and the empirical evidence suggest that there are fewer bankruptcies in prosperous industries and when the economy is in good shape. We argue that this association is weaker for bankruptcies that are driven by technology competition. The intuition is as follows. Technological innovations typically enhance the economy, and particularly the technology-intensive industries (e.g., Hsu, 2009; Bena and Garlappi, 2011). Yet, at the same time, these innovations put the firms that lose in the innovation competition at a serious disadvantage, which could propel them toward bankruptcy (e.g., Solt, 1993; Fogel, Morck, and Yeung, 2008; Garleanu, Kogan, and Panageas, 2009). 
The third hypothesis poses that bankruptcies that are driven by technology competition are more costly. This is due to a rapid decline in demand for products of the "old technologies", higher depreciation for obsolescent equipments and inventories, the poorer reputation of firms that do not keep up with advances in technology, and the costs of potential patent litigation. In other words, while bankrupt firms typically experience a gradual deterioration in performance, a firm that loses in the technology competition could find itself very quickly without any competitive strength.

We test these three hypotheses using the detailed patent data of U.S. public firms over 1976-2005. Patent data are considered the most direct measure of firm-level innovation output in the accounting and economics literature (e.g., Pakes and Griliches, 1984; Pakes, 1985; Holthausen, Larcker, and Sloan, 1995; Francis and Smith, 1995; Deng, Lev, and Narin, 1999; Bastin and Hubner, 2006), and have several advantages for assessing technological competitiveness. First, unlike research and development (R\&D) expenditures, which involve uncertainty and often inefficiency (see, e.g., Jensen, 1993), patents are realized technologies affecting future operating performance and are publicly traded (see Lev, 2001). Second, patents draw competition because they are proprietary and exclusive. Third, as patent competition and litigation have surged in a variety of industries, many firms have realized the necessity of defensive patent filings (see, e.g., Hall, 2004; Hall and Ziedonis, 2007). Fourth, patents are a powerful tool in hindering competitors or creating income from royalties (see, e.g., Lerner, 1995). In fact, many major patent-filing firms, such as Texas Instruments Inc. and Intel Corporation, have their own litigation teams to monitor their rivals’ technology activities. 
The empirical evidence supports our hypotheses. We first find that patent competition predicts future bankruptcies at three different levels. At the aggregate level, an increase in patent activity, especially in technology-intensive industries, leads to more bankruptcies. At the industry level, the number of patent issues in a technology-intensive industry is positively associated with bankruptcy among the firms in the industry that did not receive patents recently. This relation remains significant in the presence of well-used bankruptcy predictors, namely Z-score, credit rating, and the KMV measure. At the firm level, we propose a two-factor measure of a firm's technology competitiveness. The first factor captures the ability of a firm to create patents, adjusted to its R\&D effort; and the second factor captures the intensity of the technology competition in the industry the firm belongs to. Logit regressions show that both factors significantly predict firm bankruptcy. Furthermore, our two-factor model outperforms Z-score, credit rating, and the KMV measure in predicting bankruptcy. Technology competition hence explains a substantial and distinct part of corporate bankruptcy. These findings strongly support the first hypothesis.

Second, we assess the effect of technology competition on the relation between macroeconomic conditions and bankruptcy. At both industry and firm levels, the likelihood of bankruptcy as a result of patent competition is less sensitive to the business cycle and industry growth, as posited by our second hypothesis. Thus, technological innovations, which typically enhance market and industry conditions, also severely exacerbate the performance of firms that do not move forward with the changes in technology. 
Third, we examine whether firms that go bankrupt as a result of technology competition have higher indirect bankruptcy costs, as measured by the declines in accounting earnings and stock prices. Consistent with the third hypothesis, indirect bankruptcy costs are significantly higher for technology-related bankruptcies than for ordinary bankruptcies, and these costs increase with the intensity of the patent competition.

The remainder of the paper is organized as follows. The next section motivates the economic association between technology competition and corporate bankruptcy. Section II models the effect of innovation on bankruptcy and states our set of hypotheses. Section III describes the data and variable estimation. Section IV tests the hypotheses, and Section V concludes.

\section{The Role of Technology Competition in Corporate Bankruptcy}

Predicting corporate bankruptcy, or assessing the extent of financial distress, has been studied for over four decades. Models to measure the probability of bankruptcy are constructed using a variety of techniques. These include multiple discriminant analysis (e.g., Altman, 1968; Aziz, Emanuel, and Lawson, 1988); multiple choice analyses, such as logit (e.g., Ohlson, 1980; Zavgren, 1985; Shumway, 2001; Campbell, Hilscher, and Szilagyi, 2008) and probit (e.g., Zmijewski, 1984); and contingent claim frameworks (e.g., Crosbie and Bohn, 2002).

The measures of bankruptcy risk are based mostly on financial ratios that indicate current financial status (e.g., book leverage), profitability (e.g., ROA, profit margin), liquidity (e.g., current ratio), efficiency (e.g., asset turnover), growth prospects (e.g., 
market-to-book ratio), and more. To the best of our knowledge, no measure directly incorporates the ongoing technology progress of the firms, and specifically the extent of its competence. A poor status of a firm in the technology race might not be reflected in its current financial ratios, but could still have a great impact on performance in the upcoming years, which could mean quick and costly bankruptcy.

Technology competition has been recognized as a critical determinant of the industry dynamics. Griliches (1984) and Pakes (1985) both show that firms’ R\&D expenses and patent activities have positive effects on their stock prices. Cuneo and Mairesse (1984) and Griliches (1984) show a strong relation between productivity and R\&D investment in both the U.S. and France. Dierickx and Cool (1989) argue that R\&D capability is a valuable and sustainable asset in a competitive industry due to the lack of tradability. Greenwood and Jovanovic (1999) and Hobijn and Jovanovic (2001) show that new technologies are devastating for incapable old firms and obsolete industries in the long run. Moreover, the most recent work by Garleanu, Kogan, and Panageas (2009) suggests that innovation intensifies product competition and lowers the profits and values of existing firms. All these studies indicate that the technological competence of a firm affects its likelihood to survive in the long run.

It is not an overstatement to say that today's patent system is a major battlefield for corporations. Patent competition has become fierce since the establishment of a patentspecialized court (the Court of Appeals for the Federal Circuit, CAFC) in 1982 and a few highly publicized patent infringement cases in the mid-1980s (see Petruzzi, Del Valle, and Judlowe, 1988; Hall, 2004). Bessen and Meurer (2005) find escalating patent litigations; the annual number of total patent lawsuits doubled from 1984 to 1999. Such a 
surge of patent competition should not be surprising, as there is a self-reinforcing loop between more patent filings and more patent litigations. That is, escalating patent competition is an unavoidable consequence as technology advances and patent regulation becomes stronger.

For individual firms, patent competition can sometimes be devastating. A patent assignee firm can request a preliminary injunction to forestall infringement that would impose legal expenditures and operation costs on its competitors (see Lanjouw and Lerner, 2001). Moreover, announcement of patent infringement litigation has a negative impact on a defendant's reputation and stock price (see, e.g., Bhagat, Brickley, and Coles, 1994; Lerner, 1995), making it harder for a defendant firm to survive the court order. Finally, once a dispute is resolved by the court, litigation costs for the party that loses could be very high (see Lerner, 1995; Hall, 2004). As all these costs are driven by technology competition, bankruptcies are expected to be more costly in technologyintensive industries.

The work of Franzen, Rodgers, and Simin (2007) could be most related to our study as they also argue that the traditional measures of financial distress become less accurate in recent decades and require adjustments such as including information about technology development. Their research, however, is different from our study in many aspects. They aim to demonstrate the distortion in accounting-based distress measures due to the conservative treatment of $R \& D$ expenses, while we propose the causality between technology competition and bankruptcy. Their main suggestion is to modify Ohlson’s (1980) bankruptcy prediction model by capitalizing R\&D expenditures, while we present a new prediction model with patent-based factors. 
Our study is also related to the work of Acharya and Subramanian (2009) and Acharya, Baghai, and Subramanian (2010). While we analyze how technological innovations lead to bankruptcy, they investigate how legal environment factors including bankruptcy laws and labor laws affect firms’ innovation decisions.

\section{A Simple Model and Testable Hypotheses}

We consider a standard two-date setup with two firms in a representative industry. At date 1 the value of Firm $i$ 's total assets is $K_{i}$. The assets are financed by both equity and debt with a face value $D_{i}$ that matures at date 2 (for simplicity we assume no taxes and a zero coupon rate). ${ }^{2}$ During the period between dates 1 and 2 , both firms compete in a technology race; let $A_{i}$ be an indicator variable that represents the innovation success of Firm $i$. That is, we consider three possible scenarios. In the first scenario Firm 1 innovates and patents a new technology, and Firm 2 does not innovate, i.e., in this case $A_{1}=1$ and $A_{2}=0$. The second scenario is the opposite case, i.e., $A_{1}=0$ and $A_{2}=1$. And in the third scenario there is no innovation, i.e., $A_{1}=A_{2}=0$. Since a patent is an exclusive right, we do not consider the possibility that $A_{1}=A_{2}=1$. Let $P_{1}, P_{2}$, and $P_{3}$ be the probabilities at date 1 of these three scenarios. Since the probability of innovation in the industry is given by $P_{1}+P_{2}$, and since an innovation benefits one firm and hurts the other, $P_{1}+P_{2}$ measures the level of technology competition in the industry. ${ }^{3}$

\footnotetext{
${ }^{2}$ We assume that the firm's leverage is taken as given as our objective is to assess the effect of innovation on bankruptcy when the debt is already in place. However, we recognize that the choice of leverage can be endogenous to the firm's innovative investment plans, as suggested by Liu and Wong (2011).

3 Aghion, Bloom, Blundell, Griffith, and Howitt (2005) model a general relation between innovation and product market competition. Our model however assumes that the competition is exclusively over new technologies, as our objective is to analyze the effect of the innovation competition on bankruptcy, where individual firms are price takers.
} 
The value of Firm $i$ at date 2 can thus be viewed as a sum of two components. The first one is the firm's operating cash flow, designed as: ${ }^{4}$

$$
\left(C_{i}+A_{i}\right) K_{i} \varepsilon
$$

where $C_{i}>0$ denotes a scaling parameter, and $\varepsilon$ denotes the uncertain macroeconomic condition that affects both firms' operating profits, and follows a normal distribution $N\left(\mu_{\varepsilon}, \sigma_{\varepsilon}^{2}\right)$. The second component is the residual value of total assets, which is set to

$$
\left[1-\gamma\left(A_{1}+A_{2}\right)\right] K_{i}
$$

where $0<\gamma<1$. Note that while the firm's own innovation success positively affects its operating cash flows, the aggregate innovation activity has a negative effect on the firm's residual value of physical capital. This is because innovations make dated factories and equipments less productive and deteriorate their market value.

Finally, as Firm $i$ has debt in place, it will go bankrupt if the value of its total assets at date 2 is lower than the face value of debt, i.e.,

$$
\left(C_{i}+A_{i}\right) K_{i} \varepsilon+\left[1-\gamma\left(A_{1}+A_{2}\right) K_{i}\right]<D_{i}
$$

In the next subsections we analyze the model implications in terms of prediction ability, macroeconomic effects, and bankruptcy costs, and accordingly posit our testable hypotheses.

\section{A. Technology Competition and Bankruptcy Predication}

We argue that a firm's relative position in the technology competition and the aggregate- and industry-level technological development can explain future bankruptcy. Figure 1 shows the effects of innovation ability and leverage ratio on the probability of

\footnotetext{
${ }^{4}$ This form of operating cash flow is motivated by Liu, Whited, and Zhang (2009) and reflects a constant return to scale production function with a fixed product price.
} 
bankruptcy for a representative firm (Firm 1) assuming the following values: $K_{1}=1$, $C_{1}=0.5, \gamma=0.5, \mu_{\varepsilon}=1, \sigma_{\varepsilon}=1$, and $P_{1}+P_{2}=0.5$, where $P_{1}$ varies between 0 and 0.5 , and $D_{1}$ varies between 0.5 and $1 .{ }^{5}$ First, the probability to go bankrupt increases with the leverage ratio; this result is very intuitive and consistent with the common bankruptcy prediction models that use leverage as a major input. Second, and more interestingly, the bankruptcy risk significantly increases when the probability of the firm to innovate decreases, especially at the high levels of leverage. The implication of this result is that the ability of a firm to innovate contains information about its likelihood to go bankrupt over that captured by the leverage ratio.

Figure 2 shows how the level of technology competition affects the probability of bankruptcy. We measure technology competition by the probability of aggregate innovation, $P_{1}+P_{2}$, which varies between 0 and 0.5 , where the two firms have the same probability to innovate. The remaining parameter values are as in Figure 1. Consistent with the intuition discussed above, the figure indicates that more innovation activities in the industry could lead to more bankruptcies.

These results suggest that innovation activities can explain subsequent bankruptcy, and lead to three sub-hypotheses at the aggregate, industry, and firm levels.

H1a: The increase in total patents reflects more severe technology competition overall, which leads to more bankruptcies.

H1b: The increase in industry patents reflects more severe technology competition within the industry, which leads to more bankruptcies among the firms incapable of generating patents.

\footnotetext{
${ }^{5}$ The implications of the model are not sensitive to the values of these parameters.
} 
H1c: Individual firms are more likely to go bankrupt if (i) they fall farther behind their competitors in patent competition, and (ii) the patent activity in the industry is more intense.

\section{B. Technology-Related Bankruptcies and Macroeconomic Conditions}

The conventional wisdom is that there should be more bankruptcies in fading industries or in recession years (see, e.g., Denis and Denis, 1995; Vassalou and Xing, 2004). We predict that bankruptcies that are driven by technology competition are less related to macroeconomic conditions. This is due to the duel effect of technology: on the one hand, technological innovations enhance the economy and typically lead to industry growth, and on the other hand, they significantly aggravate the standing and performance of firms that do not develop new technologies.

Figure 3 shows how the effect of aggregate innovation $\left(P_{1}+P_{2}\right)$ on bankruptcy risk interacts with the effect of the state of the economy, measured by $\mu_{\varepsilon}$, which varies between 0.75 and 1.25. We use the same parameter values in Figures 1 and 2, where the face value of debt is set to 0.7 . As expected, the probability of bankruptcy is inversely related to the economy state. And as we argue, the probability of bankruptcy is also significantly increasing with the aggregate innovation activity, which could make the economy state less dominant in explaining bankruptcy.

We thus propose two sub-hypotheses positing that the effect of technology competition is weakening the effect of business cycle and industry growth on bankruptcy: H2a: Technology-related bankruptcies are less sensitive to the business cycle. H2b: Technology-related bankruptcies are less sensitive to the industry growth. 


\section{Costs of Technology-Related Bankruptcies}

The costs of bankruptcy are typically divided into direct costs that are associated with the bankruptcy process (e.g., legal, accounting, and other professional fees) and indirect costs that arise when a firm is approaching bankruptcy (e.g., loss of reputation, clients, suppliers, employees, potential business deals, and partners). We focus on indirect bankruptcy costs, which appear to be more significant than direct costs (see, for example, Warner, 1977; Altman, 1984; Opler and Titman, 1994) and more related to technology competition.

We argue that indirect bankruptcy costs should be higher in technology-related bankruptcies for several reasons: (1) when a new technology is developed by competitors and becomes accepted in the market, the firms without the technology could experience a significant decline in demand for their products due to the short life cycle of hi-tech products; (2) in the presence of new technologies, all inventories and equipments associated with the old technologies depreciate very fast; (3) firms that fall behind in the technology-based competition could very quickly lose their reputation as strong players in the industry; and (4) operations of the defendant in a patent litigation could be shut down by court order.

The proposed model justifies our argument. We measure the indirect bankruptcy costs by the reduction in Firm 1's book value between dates 1 and 2:

$$
K_{i}-\left\{\left(C_{i}+A_{i}\right) K_{i} \varepsilon+\left[1-\gamma\left(A_{1}+A_{2}\right) K_{i}\right]\right\} .
$$

We define a technology-related bankruptcy as an event where the representative firm (Firm 1) goes bankrupt and the competing firm (Firm 2) is innovating (i.e., $A_{1}=0$ and $A_{2}=1$ ). And we define an ordinary bankruptcy as an event where Firm 1 goes 
bankrupt and no firm is innovating (i.e., $A_{1}=A_{2}=0$ ). Thus, the cost of a technologyrelated bankruptcy is

$$
K_{i}-\left[C_{i} K_{i} \varepsilon+(1-\gamma) K_{i}\right]
$$

where $\left[C_{i} K_{i} \varepsilon+(1-\gamma) K_{i}\right] \sim N\left(C_{i} K_{i} \mu_{\varepsilon}+(1-\gamma) K_{i}, C_{i}^{2} K_{i}^{2} \sigma_{\varepsilon}^{2}\right)$.

This means therefore that the expected bankruptcy cost is given by

$$
K_{i}-E\left[C_{i} K_{i} \varepsilon+(1-\gamma) K_{i} \mid C_{i} K_{i} \varepsilon+(1-\gamma) K_{i}<D_{i}\right] \text {, }
$$

which, based on the conditional expectation of a normally distributed variable, equals:

$$
K_{i}-E\left[C_{i} K_{i} \varepsilon+(1-\gamma) K_{i}-C_{i} K_{i} \frac{\phi(z)}{\Phi(z)}\right],
$$

where $z=\frac{D_{i}-C_{i} K_{i} \varepsilon-(1-\gamma) K_{i}}{C_{i} K_{i}}$, and $\phi($.$) and \Phi($.$) are the density and cumulative$ functions of a standard normal distribution.

Similarly, the cost of an ordinary bankruptcy is

$$
K_{i}-\left[C_{i} K_{i} \varepsilon+K_{i}\right]
$$

where $\left[C_{i} K_{i} \varepsilon+K_{i}\right] \sim N\left(C_{i} K_{i} \mu_{\varepsilon}, C_{i}^{2} K_{i}^{2} \sigma_{\varepsilon}^{2}\right)$, which implies that the expected bankruptcy cost is given by

$$
K_{i}-E\left[C_{i} K_{i} \varepsilon+K_{i} \mid C_{i} K_{i} \varepsilon+K_{i}<D_{i}\right]=K_{i}-E\left[C_{i} K_{i} \varepsilon+K_{i}-C_{i} K_{i} \frac{\phi(z)}{\Phi(z)}\right],
$$

where $z=\frac{D_{i}-C_{i} K_{i} \varepsilon-K_{i}}{C_{i} K_{i}}$.

Figure 4a compares the costs of technology-related and ordinary bankruptcies for different levels of leverage ratio, where $K_{1}=1, C_{1}=0.5, \gamma=0.5, \mu_{\varepsilon}=1, \sigma_{\varepsilon}=1$, and $P_{1}=P_{2}=0.5$. The results show first that in both cases the expected bankruptcy cost 
decreases with a rise in leverage. This relation is intuitive as a firm is likely to lose more of its value if it could not pay a lower amount of debt. More importantly, for any level of leverage the expected cost of technology-related bankruptcy exceeds that of ordinary bankruptcy.

Because bankruptcy costs can be affected by macroeconomic conditions, we compare the costs of the two types of bankruptcies at different levels of the state of the economy, measured by $\mu_{\varepsilon}$ (Figure 4b), and the risk of the economy, measured by $\sigma_{\varepsilon}$ (Figure 4c), where the face value of debt is set to 0.7. As expected, bankruptcy costs in general decrease when the economy improves and increase when the economy becomes riskier. And consistent with Figure 4a, technology-related bankruptcies are more costly than ordinary bankruptcies.

We thus propose two sub-hypotheses:

H3a: Technology-related bankruptcies incur higher indirect bankruptcy costs.

H3b: Indirect bankruptcy costs rise with the intensity of the patent competition.

\section{Data and Variable Estimation}

\section{A. U.S. Patent Data}

We first collect 22,071 company names from the CRSP/Compustat database over the period 1976-2005. We then obtain each public firm's all types of patents (utility, design, plant, and reissue) by manually searching their names in the assignee category of the Patent Full-Text and Image Database (PatFT), which contains the details of all patent applications being approved by the U.S. Patent and Trademark Office (USPTO) 
database. ${ }^{6}$ Each patent is dated by two time placers: application dates and approval dates. We thus count each public firm's annual successful patent applications (patent counts dated by application years) and annual patent issues (patent counts dated by approval dates). The matching process generates 1,099,434 successful patent applications and 998,272 patent issues owned by 5,024 public firms over the sample period. It is important to note that, unlike previous studies that typically use micro patent datasets (e.g., Holthausen, Larcker, and Sloan, 1995; Francis and Smith, 1995; Deng, Lev, and Narin, 1999), our sample includes all public firms' patent records. For the firms that changed their names or experienced mergers and acquisitions, we match their patents using the permanent numbers recorded in the CRSP/Compustat database.

\section{B. Technology-Intensive Industries}

For each 4-digit SIC code industry, we calculate the percentage of firms filing for at least one successful patent application in every calendar year. The time series average of annual percentages of applications in an industry (denoted Pct $A p$ ) serves as a measure of technology competition in that industry. We then define technology-intensive industries as industries with a successful patent application rate higher than $25 \%$. The threshold ratio approximates the percentage of firms owning patents in the whole CRSP/Compustat database (5,024 out of 22,071). We obtain a total of 62 technology-intensive industries, listed in Table I. This group of industries seems appropriate to represent an environment of technology-driven competition, as it includes most of the highly technological

\footnotetext{
${ }^{6}$ Our sample does not include private firms that do not appear in CRSP/Compusat database. Yet, the data selection does not seem to affect the validity of our conclusions, as venture capital-backed start-up companies with patenting record typically have significantly lower bankruptcy probability than those without patenting record (see Cao and Hsu, 2010). Moreover, using public firms sample is consistent with the literature standard and provides a good comparison to previous studies.
} 
industries, such as computers, semiconductors, and biological and pharmaceutical industries.

\section{Bankruptcy Classification}

We use the CRSP delisting file to classify bankrupt firms. Although CRSP has a specific code for bankruptcy, we include all the delisting categories associated with poor performance such as 'liquidation' and 'dropping due to bad performances' in the bankruptcy group, because they relate to technology competition in the same way as bankruptcy does.

\section{Bankruptcy Prediction Models}

We use three measures of bankruptcy risk that represent different methodologies as control variables in our tests. The first one is Altman’s (1968) Z-score, a widely used model of bankruptcy prediction. ${ }^{7}$ The second is S\&P bond credit rating, provided by Compustat, where a higher value indicates higher default risk. The third, known as the KMV approach, is built on Merton’s (1974) default model (see Ronn and Verma, 1986; Crosbie and Bohn, 2002; Hillegeist, Keating, Cram, and Lundstedt, 2004; Leland, 2004). ${ }^{8}$

\footnotetext{
7 Altman's Z-score model for predicting bankruptcies is: Z-score=1.2(Working capital/Total assets)+1.4(Retained earnings/Total assets)+3.3(Earnings before interest and taxes/Total assets)+0.6(Market value of equity/Book value of total liabilities)+0.999(Sales/Total assets).

${ }^{8}$ The KMV measure of default risk is estimated using a two-equation system. The first expresses the value of the firm's equity as the value of a call option on the firm's total asset using the Black and Scholes (1973) formula: $V_{E}=V_{A} N\left(d_{1}\right)-F e^{-r T} N\left(d_{2}\right)$, where $V_{E}$ is the firm's equity value, measured by the stock price multiplied by the number of shares outstanding; $N(\cdot)$ is the cumulative function of a standard normal distribution; $d_{1}=\left[\ln \left(V_{A} / F\right)+\left(r+\sigma_{A}^{2} / 2\right) T\right] /\left[\sigma_{A} \sqrt{T}\right], d_{2}=d_{1}-\sigma_{A} \sqrt{T} ; F$ is the face value of debt, measured by the book value of total liabilities of the firm; $r$ is the risk-free rate, measured by the one-year Treasury bill yield; $T$ is the time to maturity of debt, measured by the weighted-average maturity of the short- and long-term debt; and $V_{A}$ and $\sigma_{A}$ are the unobservable market value and volatility of the firm's total assets. The second equation, a straightforward derivation of Ito's lemma, represents the relation between equity volatility, $\sigma_{E}$, measured by the realized monthly stock return volatility in the subsequent year, and asset volatility: $\sigma_{E}=\left[V_{A} N\left(d_{1}\right) \sigma_{A}\right] / V_{E}$. As there are no closed-form solutions to $V_{A}$ and $\sigma_{A}$, we solve the two
} 
All the inputs required to calculate the three measures are taken from the CRSP/Compustat database.

\section{E. Descriptive Statistics}

Table II reports descriptive statistics of the important variables for technologyintensive industries and other industries. The technology-intensive industries represent $30.4 \%$ of the market capitalization of all listed industrial companies, indicating that these industries account for a substantial part of the overall economy. Firms in technologyintensive industries are usually larger, have lower leverage ratios and higher market-tobook ratios, and invest more in $\mathrm{R} \& \mathrm{D} .^{9}$ These differences are expected, as technologyintensive firms are usually capital-intensive with more growth opportunities. Another interesting result is that the average firms operating in technology-intensive industries appear to experience less financial distress than average firms in other industries, as indicated by all three measures of bankruptcy risk.

\section{Empirical Tests}

\section{A. Hypothesis 1a}

Hypothesis 1a concerns the effect of total patents on bankruptcy frequency. We test it using the time series regression:

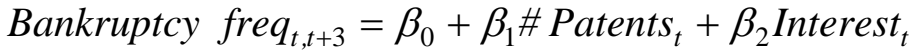

$$
\begin{aligned}
& +\beta_{3} \text { Default }_{t}+\beta_{4} \text { Re cession }_{t}+\varepsilon_{t} \text {, }
\end{aligned}
$$

equations simultaneously using initial values of $V_{E}+F$ and $\sigma_{E}$. The probability of bankruptcy is defined as the probability that the face value of debt exceeds the asset value at maturity, and is given by $1-N(d 2)$, which is equivalent to the probability of not exercising a European call option.

${ }^{9}$ Size is measured by the market value of equity, calculated by the stock price times the number of shares outstanding; market-to-book ratio is equity market value divided by equity book value; leverage is the book value of debt divided by the book value of total assets; and R\&D investment is measured as a fraction of the book value of total assets. 
where 'bankruptcy freq' denotes the percentage of firms that went bankrupt during the next three years; and '\# patents' is the total patent issues of all firms in the sample over the past one or three years. To eliminate marketwide effects on bankruptcy frequency, the regression also includes three variables that represent the state of the economy: the interest rate, measured by the nominal return on 1-month Treasury bills; the default spread, which is the yield spread between long-term Baa- and Aaa-rated securities (taken from the Federal Reserve Bank of St. Louis's website); and the National Bureau of Economic Research (NBER) recession indicator. To control for a positive time trend in patent activity, we also consider the annual change in number of patents as the dependent variable. Figure 5 provides a first indication for a positive effect of change in patent activity on the likelihood of bankruptcy in technology-intensive industries.

The regression results are reported in Table III, where the Newey-West (1987) standard errors are used to correct for serial correlation. The upper box in Panel A shows regressions for patent issues in the past year. We find first that when the sample is confined to technology-intensive industries, the number of patents significantly predicts bankruptcy frequency. As a single explanatory factor, the number of patents in the past year explains $31.2 \%$ of the variation in bankruptcy frequency with a $p$-value of 0.007 . The effect of total patents remain significant when we control for marketwide variables ( $p$-value of 0.037 ), indicating that the results are not driven by business cycle conditions.

Second, expanding the sample to all firms in all industries shows a similar but somewhat weaker effect. The $p$-values of total patents are 0.118 and 0.204 , with an explanatory power of over $10 \%$ of future bankruptcy frequency. The less significant results are expected, as patents should play a more influential role in technology- 
intensive industries. The lower box in Panel A shows similar, albeit weaker, results when we use total patents in the past three years as the explanatory variable. Examination of the effect of the change in patent activity on future bankruptcy frequency (reported in Panel B) shows even stronger results, where the $p$-values range between 0.000 and 0.037 .

Overall, Table III prompts the observation that more intense patent activity leads to more bankruptcies. These findings strongly support hypothesis 1a, and are consistent with the argument of Greenwood and Jovanovic (1999) and Hobijn and Jovanovic (2001) that new technologies reshape industry organization by forcing incapable older firms and obsolete industries out of business.

\section{B. Hypothesis $1 b$}

Hypothesis $1 \mathrm{~b}$ addresses the industry-specific relation between patents and bankruptcies in technology-intensive industries. To test it we run the pooled regression:

$$
\begin{aligned}
& \text { Bankruptcy } \text { freq }_{i,(t, t+3)}=\beta_{0}+\beta_{1} \# \text { Patents }_{i, t}+\beta_{2} \text { Mean }_{i, t} \\
& +\beta_{3}{\text { Spec. } \text { Rating }_{i, t}}+\beta_{4} \text { Mean KMV } \\
& i, t,
\end{aligned}
$$

where 'bankruptcy freq' is the number of firms in industry $i$ that did not issue patents in the past one or three years and went bankrupt during the next three years, divided by the number of firms that did not issue patents in the past one or three years; and '\# patents' is the number of patents issued in the industry over the past one or three years. To examine whether the patent activity incorporates information relevant for future bankruptcy that is not captured by common bankruptcy predictors, we include in the regression the following variables: the mean $Z$-score, the proportion of firms with speculative-grade bonds (ratings of $\mathrm{BB}+$ or lower), and the mean $\mathrm{KMV}$ measure. 
Panel A of Table IV shows industrywide regression results for patents issued in the past year. All regressions strongly indicate that patent activity increases the bankruptcy risk of the firms that do not issue patents. As a single explanatory variable, the coefficient of industry patent issues has a $p$-value of 0.000 , and it is barely affected when we add each of the three bankruptcy predictors. When we include all bankruptcy predictors in the regression, the coefficient of industry patent issues remains significant ( $p$-value of 0.048 ), and it increases the $R$-square from $7.5 \%$ to $8.6 \%$.

Panel B of Table IV shows very similar results for industry patent issues over the past three years, indicating a robust effect of industry patent activity on bankruptcy that is not captured by current financial status or operating performance in technology-intensive industries. Table IV therefore supports hypothesis $1 \mathrm{~b}$, implying that we should expect more incapable firms to be driven out of business in a rapidly evolving industry. For instance, the rise and fall of an internet company would occur faster than that of a lumber company because the technologies used in traditional industries usually develop more slowly.

\section{Hypothesis 1c}

We test hypothesis 1c concerning the association between a firm's position in the technology competition and its likelihood to go bankrupt using a logit regression:

$$
\begin{gathered}
\text { Bankruptcy indicator }_{i,(t, t+3)}=\beta_{0}+\beta_{1} \# \text { Firm } P T-R D_{i, t}+\beta_{2} \text { Ind. }_{\text {PI }} I_{i, t} \\
+\beta_{3} \text { score }_{i, t}+\beta_{4} \text { Credit rating }_{i, t}+\beta_{5} K M V_{i, t}+\varepsilon_{i, t},
\end{gathered}
$$

where 'bankruptcy indicator' is an indicator variable equal to one if firm $i$ went bankrupt in the following three years, and zero otherwise. The independent variables include two patent-based factors. The first factor (Firm PT-RD) measures the firm's relative strength 
in the industry patent competition. The term $P T$ is the number of the firm's patent issues in the past one or three years, divided by the total number of patents issues in the industry. For example, if one firm owns most patents in its industry, it dominates the industry in technology and is thus less likely to experience financial distress. Note that we use patent issues, not patent applications, because only approved patents can be used to secure properties and attack competitors. While $P T$ focuses on the ultimate result in terms of relative number of patents, it does not take into account the cost of innovation. A firm might not have generated many patents recently but still be able to compete successfully in its industry because its R\&D cost is relatively low (see, e.g., Dierickx and Cool, 1989). Similarly, a firm may strategically postpone its innovation efforts at certain times (e.g., for reorganization purposes), so both its $R \& D$ expenses and the number of patent issues are low, but its status in the competition remains strong. We thus subtract from $P T$ the term $R D$, which is the firm's average $R \& D$ expenditures in the past three years scaled by its equity market value. ${ }^{10}$

The second factor in regression (12), Ind. PI, measures the intensity of the technology competition in the industry. It is defined by the total number of successful patent applications in the industry in the year, divided by the industry size (the sum of equity market values of all firms in the industry). As discussed above, firms in fast-growing, highly technological industries confront harsher technology competition, and are more likely to go bankrupt because of fierce market competition and potentially fatal patent litigations. The regression also includes the three bankruptcy predictors: Z-score; a credit rating dummy variable that equals one if the rating is $\mathrm{BB}+$ or lower (speculative-grade), and zero otherwise (investment-grade); and the KMV measure.

\footnotetext{
${ }^{10}$ The results are robust when using Firm PT only.
} 
To control for industry and time effects on the likelihood of a firm to go bankrupt, we examine the results using fixed effects regressions for each 2-digit SIC code and year in the sample. And as this regression (and others below) relies on firm-level data, the standard errors are clustered by individual firms. ${ }^{11}$

The results reported in Table V indicate that both the firm's technology competence and the industry technology intensity explain its likelihood to go bankrupt. The $p$-values are extremely low when only the two patent-based factors are included in the regression, and remain very low in the presence of each bankruptcy predictor. That is, consistent with our earlier findings, patents provide additional information over common bankruptcy prediction measures.

We recognize that the results in Table $\mathrm{V}$ may be affected by potential endogeneity, assuming that there are unobserved firms-specific characteristics that influence a firm's patent activity and bankruptcy risk. To address the endogeneity concern, we employ the following two-stage regression procedure. In the first stage we run a linear regression of the firm's relative strength in the industry patent competition (Firm PT-RD) on two instrumental variables (IVs) that are associated with the firm's patent activity and not with its likelihood to go bankrupt. The first IV is patent owning percentage, which denotes the fraction of all public firms in every 2-digit SIC industry that have at least one patent registered in the USPTO over the past five years. The second IV is R\&D cost per patent, defined as the total five-year R\&D expenditures in every 2-digit SIC industry divided by the number of patents in that industry over the past five years. These two IVs measure the incentive of firms to file patents in each industry, and hence should be closely related to their patent activities. Yet, they should not affect the individual firm's

\footnotetext{
${ }^{11}$ Using the Newey-West (1987) procedure for panel data yields similar results.
} 
bankruptcy risk as they are unrelated to its financial situation. We verify the validity of the two IVs (unreported). The first stage regression thus generates the predicted Firm PT$R D$.

In the second stage we run a probit regression, where the dependent variable is the bankruptcy dummy (equals one if the firm went bankrupt in the following three years, and zero otherwise) and the independent variables include the predicted Firm PT-RD, Ind. PI, Z-score, credit rating dummy, KMV measure, industry dummies, and year dummies. The results of the second stage probit regressions reported in Table VI are consistent with the results in Table V. The predicted Firm PT-RD has a significant effect on its likelihood to go bankrupt (the $p$-values remain extremely low). Our empirical tests thus suggest that the proposed innovation-bankruptcy relation cannot be attributed to endogeneity.

We also recognize a potential reverse causality relation, given that firms facing financial difficulties might under-invest in research and patent activity and are also more likely to go bankrupt in the future (e.g., Li, 2010). To control for the reverse causality effect, we include lagged Z-score, credit rating, and the KMV measure, in the predictive models of Tables V and VI (unreported). That is, adding these lagged variables controls for the possible effect of the extent of financial distress in prior years on current patent activity, and thus on bankruptcy risk. We find that Firm PT-RD remains significant in forecasting future bankruptcy. This suggests that the relative strength in the patent competition has a distinct explanatory power for bankruptcy, which is not captured by prior financial difficulties. 
Figure 6 visualizes the findings of Table $\mathrm{V}$ to provide an assessment of the economic significance of the proposed patent-based bankruptcy predictors. The first column (sample frequency) denotes the unconditional probability of bankruptcy (6.78\%). A onestandard deviation change in Firm PT-RD and Ind. PI increases the bankruptcy probability to $9.25 \%$ and $7.94 \%$, respectively. When both factors change by one standard deviation, the conditional bankruptcy probability surges to $10.81 \%$, which is higher than the effects produced by each of the three bankruptcy predictors. Note that the 4 percentage points increase in bankruptcy probability created by Firm PT-RD and Ind. PI is about the difference in the default rates of firms with Aaa-rated and B-rated bonds according to Moody's (see Hamilton, 2004), which provides another indication for the economic importance of the results.

The empirical evidence overall supports all three testable sub-hypotheses, suggesting that intense patent competition increases a firm's possibility of bankruptcy. Moreover, technology competition explains a distinct part of firm bankruptcy that is not captured by traditional models such as Z-score, credit rating, and the KMV measure.

\section{Hypotheses 2a and 2b}

Panel A of Table VII reports the results for hypothesis 2a, which addresses the effect of technology competition on the relation between bankruptcy and business cycle. At the industry level, we regress subsequent (one- and three-year) bankruptcy frequency in each industry on the NBER recession indicator $(R C)$ and on an interactive term between $R C$ and technology competition. We use two proxies defined earlier in Section III.B to measure industry technology competition. The first one, $P D I$, is a dummy variable that equals one for technology-intensive industries (i.e., all 4-digit SIC industries in which at 
least $25 \%$ of the firms file successful patent applications, as listed in Table I), and zero otherwise. The second one, Pct Ap, is the time series average of the annual percentages of the firms with successful patent applications in an industry, representing the intensity of the patent competition in that industry.

First, as expected, the effect of business cycle on bankruptcies is statistically significant in all regressions, validating the notion that more bankruptcies occur after recessions. Second, and more important, the coefficients of the interaction terms, $R C^{*} P D I$ and $R C^{*} P c t A p$, are both significantly negative ( $p$-values between 0.000 and 0.058), implying that bankruptcy frequency in technology-intensive industries is less sensitive to the business cycle.

We also examine the hypothesis at the firm level using a logit regression. The dependent dummy variable equals one if the firm went bankrupt in the following one or three years, and zero otherwise. The independent variables are the same as in the industry-level regressions: a business cycle dummy and an interaction term between the business cycle and the industry technology competition proxies. For the PDI proxy, the results are consistent with the industry-level tests, as the coefficients of the business cycle dummy and the interaction term remain positive and negative, respectively. For the Pct Ap measure is used, however, the coefficient of the interaction term is not significant.

We conduct a similar analysis to test hypothesis $2 \mathrm{~b}$ on the effect of technology competition on the relation between bankruptcy and industry growth (Panel B of Table VII). We run an industry-level linear regression of subsequent bankruptcy frequency in an industry on the industry growth $(I G$, measured by the annual percentage change in the total revenues in the industry minus the annual percentage change in the total revenues in 
all industries) and on an interaction term between $I G$ and the same proxies of industry technology competition as in Panel A (PDI and Pct Ap).

As expected, the coefficients of industry growth are significantly negative, indicating that bankruptcies are less likely to occur in prosperous industries. Consistent with the hypothesis, the coefficients of the interaction terms are all positive, although not significant for Pct Ap, suggesting that technology-related bankruptcies are less correlated with the industry success.

The results are even stronger for the firm-level logit regression, where we regress a bankruptcy dummy variable on the corresponding industry growth and the interaction term. As in industry-level regressions, the coefficients of industry growth and the interaction term are significantly negative and positive, respectively.

The results in Table VII support our proposition that bankruptcies that are driven by technology competition are less affected by macroeconomic conditions, and, even in a promising industry, the possibility of failure of a firm could be high if technology competition is fierce in that particular industry.

\section{E. Hypotheses 3a and $3 b$}

We test hypothesis 3a using a simple comparison of indirect bankruptcy costs of technology-related bankruptcies and ordinary bankruptcies. Technology-related bankruptcies include all firms that went bankrupt without issuing any patent during the three years prior to bankruptcy in technology-intensive industries. The record shows a total of 279 technology-related bankruptcies over 1976-2005.

We use two measures of indirect bankruptcy costs. The first is the sum of abnormal earnings in the three years prior to bankruptcy (scaled by asset book value), following 
Altman's (1984) method. ${ }^{12}$ The second one is the cumulative stock return in the three years prior to bankruptcy. One advantage of using stock return is that it allows a much bigger sample than abnormal earnings does, because the latter requires data on the previous ten years. Both measures are used in both raw and industry-adjusted data (calculated by subtracting the industrywide medians of the measures from the firm's raw figures).

Table VIII presents the means and medians of the indirect bankruptcy cost measures for technology-intensive industries and other industries, as well as the $p$-value of the differences (T-test for means and Wilcoxon-Mann-Whitney test for medians). The first row in the table shows that technology-related bankrupt firms suffer a greater decline in earnings when approaching bankruptcy. The mean drop in earnings for ordinary bankruptcies is $17.2 \%$, compared to $28.1 \%$ for technology-related bankruptcies (although the $p$-value of the difference is 0.178 ), and the median reduction is $16.2 \%$, compared to 25.6\% ( $p$-value of 0.069). Similar results are found when we account for industry effects (second row in the table).

The stock return comparison is consistent with the earnings differences. The third row in the table shows that technology-related bankruptcies lose $49.9 \%$ of stock price on average, while ordinary bankruptcies lose $43.1 \%$ ( $p$-value of 0.089 ). In terms of median, technology-related bankruptcies lose $76.4 \%$ of stock price, while ordinary bankruptcies lose $71.4 \%$ ( $p$-value of 0.028 ). The industry-adjusted data show even stronger results, as

\footnotetext{
${ }^{12}$ We first run a regression of the firm's annual sales on the aggregate sales in the industry in each of the past ten years. This regression's coefficients yield the firm's estimated sales for the current year. The firm's estimated profit (net income) for the current year is then given by multiplying the firm's estimated sales by its average profit margin in the past ten years. The firm's abnormal earning in each year is therefore the difference between the firm's actual and estimated profits. Finally, the firm's indirect costs are defined as the sum of its abnormal earnings in the three years prior to bankruptcy, scaled by the book value of total assets.
} 
the $p$-values of all differences are very low. The comparisons in Table VIII thus unanimously indicate that technology-related bankrupt firms suffer higher costs.

To test whether indirect bankruptcy costs increase with the intensity of the technology competition (hypothesis 3b), we regress the cost measures in Table VIII (abnormal earnings and stock returns) on industry technology competition measured with Pct Ap. The regression also includes firm size, market-to-book ratio, and leverage, as these may affect the magnitude of bankruptcy costs in particular, and earnings and stock returns in general.

The regressions in Panel A of Table IX indicate that technology competition reduces earnings, especially when raw data are used ( $p$-values of 0.084 and 0.082 ). And similarly, the regressions in Panel B indicate a very strong negative effect of technology competition on stock return, where all $p$-values are no higher than 0.001 . The lower $p$ values in the stock return tests could be attributed to the larger sample size than the size for the abnormal earnings tests.

Table IX corroborates the findings reported in Table VIII, and further suggests that technology competition is a distinct factor in explaining indirect bankruptcy costs. The results in both tables therefore support our prediction that firms confront higher indirect bankruptcy costs when they operate in an environment characterized by intense technology competition.

\section{Conclusions}

This paper analyzes the association between technology competition and corporate bankruptcy. Firms operating in technology-driven industries could find themselves very quickly in trouble with a real risk of failure, if they do not keep pace with the recent 
innovations. Moreover, the nature of highly technological industries could impose high costs on firms that lose in the competition, due to reduced or inefficient productivity, a rapid decline in demand, out-of-date equipment, shrinking market share, and various costs of potential patent litigations. Another distinctive characteristic of bankruptcies that are driven by technology competition is their relatively weak relation to macroeconomic conditions. This is because the technological innovations that typically enhance the economy also force some less capable firms into bankruptcy.

Analysis of firm-level patent data yields empirical evidence to support our hypotheses. Severe technology competition leads to a higher frequency of bankruptcy, and firms that perform poorly in technology competition are more likely to go bankrupt. Moreover, the ability of technology competition to predict future bankruptcy remains significant in the presence of common bankruptcy predictors, such as Z-score and credit rating, and even outperforms their predictive ability in technology-intensive industries. In addition, bankruptcies that are driven by technology competition are less sensitive to the business cycle and the industry growth, and result in greater declines in earnings and stock prices than ordinary bankruptcies. The findings in this study therefore suggest an important role of technology competition in corporate bankruptcy. 


\section{References}

Acharya, V.V. and K. Subramanian, 2009, "Bankruptcy Codes and Innovation," forthcoming, Review of Financial Studies 22, 4949-4988.

Acharya, V.V., R. Baghai, and K. Subramanian, 2010, "Labor Laws and Innovation,” Unpublished working paper, New York University.

Aghion, P., N. Bloom, R. Blundell, R. Griffith, and P. Howitt, 2005, “Competition and Innovation: An Inverted-U Relationship,” Quarterly Journal of Economics 120, 701728.

Altman, E.I., 1968, "Financial Ratios, Discriminant Analysis and the Prediction of Corporate Bankruptcy,” Journal of Finance 23, 589-609.

Altman, E.I., 1984, "A Further Empirical Investigation of the Bankruptcy Cost Question,” Journal of Finance 39, 1067-1089.

Aziz, A., D.C. Emanuel, and G.H. Lawson, 1988, "Bankruptcy Prediction - An Investigation of Cash Flow Based Models,” Journal of Management Studies 25, 419437.

Bastin, V. and Georges Hübner, 2006, “Concentrated Announcements on Clustered Data: An Event Study on Biotechnology Stocks,” Financial Management 35, 129-157.

Bena, J. and L. Garlappi, 2011, "Strategic Investments, Technological Uncertainty and Expected Return Externalities,” Unpublished working paper, University of British Columbia.

Bessen, J. and M.J. Meurer, 2005, “The Patent Litigation Explosion,” Unpublished working paper, Boston University.

Bhagat, S., J.A. Brickley, and J.L. Coles, 1994, "The Costs of Inefficient Bargaining and Financial Distress: Evidence from Corporate Lawsuits,” Journal of Financial Economics 35, 221-247.

Black, F. and M. Scholes, 1973, “The Pricing of Options and Corporate Liabilities," Journal of Political Economy 81, 637-654.

Campbell, J.Y., J. Hilscher, and J. Szilagyi, 2008, “In Search of Distress Risk,” Journal of Finance 63, 2899-2939.

Cao, J.X. and P. Hsu, 2010, "Patent Signaling, Entrepreneurial Performance, and Venture Capital Financing,” Unpublished working paper, Singapore Management University and University of Connecticut.

Crosbie, P.J. and J. R. Bohn, 2002, “Modeling Default Risk,” KMV LLC. 
Cuneo, P. and J. Mairesse, 1984, "Productivity and R\&D at the Firm Level in French Manufacturing.” In: Griliches, Zvi (Ed.), “R\&D, Patents, and Productivity.” The University of Chicago Press, Chicago, IL.

Deng, Z., B. Lev, and F. Narin, 1999, "Science and Technology as Predictors of Stock Performance,” Financial Analysts Journal 55, 20-32.

Denis, D.J. and D. Denis, 1995, “Causes of Financial Distress Following Leveraged Recapitalization,” Journal of Financial Economics 27, 411-418.

Dierickx, I. and K. Cool, 1989, “Asset Stock Accumulation and Sustainability of Competitive Advantage,” Management Science 35, 1504-1513.

Francis, J. and A. Smith, 1995, “Agency Costs and Innovation Some empirical Evidence,” Journal of Accounting and Economics 19, 383-409.

Franzen, L., K. Rodgers, and T. Simin, 2007, “Measuring Distress Risk: The Effect of R\&D Intensity,” Journal of Finance 62, 2391-2968.

Fogel, K., R. Morck, and B. Yeung, 2008, "Big Business Stability and Economic Growth: Is What's Good for General Motors Good for America?” Journal of Financial Economics 89, 83-108.

Garleanu, N., L. Kogan, and S. Panageas, 2009, “The Demographics of Innovation and Asset Returns,” Unpublished working paper, University of California at Berkeley.

Greenwood, J. and B. Jovanovic, 1999, “The Information-Technology Revolution and the Stock Market,” American Economic Review, Papers and Proceedings 89, 116-122.

Griliches, Z., 1984, “R\&D, Patents, and Productivity.’ Chicago: University of Chicago Press.

Hall, B.H., 2004, “Exploring the Patent Explosion,” Journal of Technology Transfer 30, 35-48.

Hall, B.H. and R.H. Ziedonis, 2007, “An Empirical Analysis of Patent Litigation in the Semiconductor Industry,” Unpublished working paper, University of California at Berkeley.

Hamilton, D.T., 2004, "Rating Transitions and Defaults Conditional on Watchlist, Outlook and Rating History.” Moody’s Special Comment.

Hillegeist, S.A., E.K. Keating, D.P. Cram, and K.G. Lundstedt, 2004, “Assessing the Probability of Bankruptcy,” Review of Accounting Studies 9, 5-34. 
Hobijn, B. and B. Jovanovic, 2001, "The Information-Technology Revolution and the Stock Market: Evidence,” American Economic Review 91, 1203-1220.

Holthausen, R.W., D.F. Larcker, and R.G. Sloan, 1995, "Business Unit Innovation and the Structure of Executive Compensation,” Journal of Accounting and Economics 19, 279-313.

Hsu, P., 2009, “Technological Innovations and Aggregate Risk Premiums,” Journal of Financial Economics 94, 264-279.

Jensen, M.C., 1993, “The Modern Industrial Revolution, Exit, and the Failure of Internal Control Systems,” Journal of Finance 48, 831-880.

Lanjouw, J.O. and J. Lerner, 2001, “Tilting the Table? The Use of Preliminary Injunctions,” Journal of Law and Economics 44, 573-603.

Leland, H.E., 2004, 'Predictions of Default Probabilities in Structural Models of Debt," Journal of Investment Management 2, 5-20.

Lerner, J., 1995, "Patenting in the Shadow of Competitors," Journal of Law and Economics 38, 463-495.

Lev, B., 2001, Intangibles: Management, Measurement and Reporting, Brookings Institution Press, Washington, D.C.

Li, D., 2010, "Financial Constraints, R\&D Investments, and Stock Returns," forthcoming, Review of Financial Studies.

Liu, L., T.M. Whited, and L. Zhang, 2009, “Investment-Based Expected Stock Returns,” Journal of Political Economy 117, 1105-1139.

Liu, Q. and K.P. Wong, 2011, “Intellectual Capital and Financing Decision: Evidence from the US Patent Data,” forthcoming, Management Science.

Merton, R.C., 1974, "On the Pricing of Corporate Debt: The Risk Structure of Interest Rates,” Journal of Finance 29, 449-470.

Newey, W.K. and K.D. West, 1987, “A Simple Positive Semidefinite Heteroskedasticity and Autocorrelation Consistent Covariance Matrix,” Econometrica 55, 703-708.

Ohlson, J.A., 1980, "Financial Ratios and the Probabilistic Prediction of Bankruptcy," Journal of Accounting Research 18, 109-131.

Opler, T.C. and S. Titman, 1994, "Financial Distress and Corporate Performance," Journal of Finance 49, 1015-1040. 
Pakes, A., 1985, “On Patents, R\&D, and the Stock Market Rates of Returns,” Journal of Political Economy 93, 390-409.

Pakes, A. and Z. Griliches, 1984, "Patents and R\&D at the Firm Level: A First Look." In: Zvi Griliches (Ed.), "R \& D, Patents, and Productivity.” The University of Chicago Press, Chicago, IL.

Petruzzi, C., M. Del Valle, and S. Judlowe, 1988, "Patent and Copyright Protection for Innovations in Finance,” Financial Management 17, 66-71.

Ronn, E. and A.K. Verma, 1986, "Pricing Risk-Adjusted Deposit Insurance: An OptionBased Model,” Journal of Finance 41, 871-895.

Scheck, J. and P. Glader, 2009, "R\&D Spending Holds Steady in Slump," Wall Street Journal, April 6, A1.

Solt, M.E., 1993, "SWORD Financing of Innovation in the Biotechnology Industry," Financial Management 22, 173-187.

Shumway, T., 2001, "Forecasting Bankruptcy More Accurately: A Simple Hazard Model," Journal of Business 74, 101-124.

Vassalou, M. and Y. Xing, 2004, “Default Risk in Equity Returns,” Journal of Finance 59, 831-868.

Warner, J.B., 1977, “Bankruptcy Costs: Some Evidence,” Journal of Finance 32, 337348.

Zavgren, C.V., 1985, "Assessing the Vulnerability to Failure of American Industrial Firms: A Logistic Analysis,” Journal of Business Finance and Accounting 12, 19-45.

Zmijewski, M.E., 1984, "Methodological Issues Related to the Estimation of Financial Distress Prediction Models," Journal of Accounting Research 22 (Supplement), 5982. 


\section{Figure 1. Effects of Firm 1's Innovation Ability and Leverage on its Bankruptcy Risk}

The figure shows the probability of Firm 1 to go bankrupt, $P\left\{\left(C_{i}+A_{i}\right) K_{i} \varepsilon+\left[1-\gamma\left(A_{1}+A_{2}\right) K_{i}\right]<D_{i}\right\}$, for different values of its probability to innovate, $P_{1}$, and its leverage, $D_{1}$. The remaining parameter values are set to: $K_{1}=1, C_{1}=0.5, \gamma=0.5, \mu_{\varepsilon}=1, \sigma_{\varepsilon}=1$, and $P_{1}+P_{2}=0.5$.

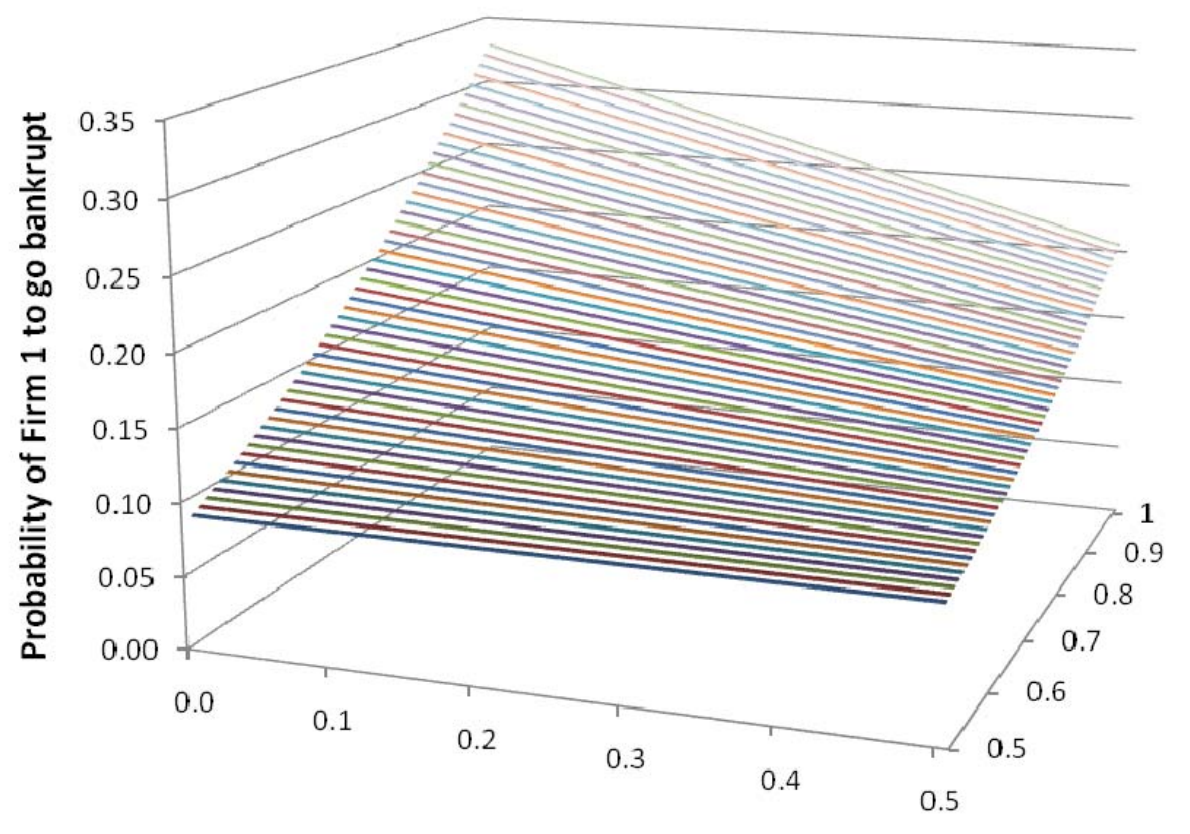

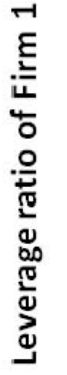

Probability of Firm 1 to innovate 


\section{Figure 2. Effects of Aggregate Innovation and Leverage on Firm 1's Bankruptcy}

\section{Risk}

The figure shows the probability of Firm 1 to go bankrupt, $P\left\{\left(C_{i}+A_{i}\right) K_{i} \varepsilon+\left[1-\gamma\left(A_{1}+A_{2}\right) K_{i}\right]<D_{i}\right\}$, for different values of the probability of aggregate innovation, $P_{1}+P_{2}$ (where the two firms have the same probability to innovate), and its leverage, $D_{1}$. The remaining parameter values are set to: $K_{1}=1$, $C_{1}=0.5, \gamma=0.5, \mu_{\varepsilon}=1$, and $\sigma_{\varepsilon}=1$.

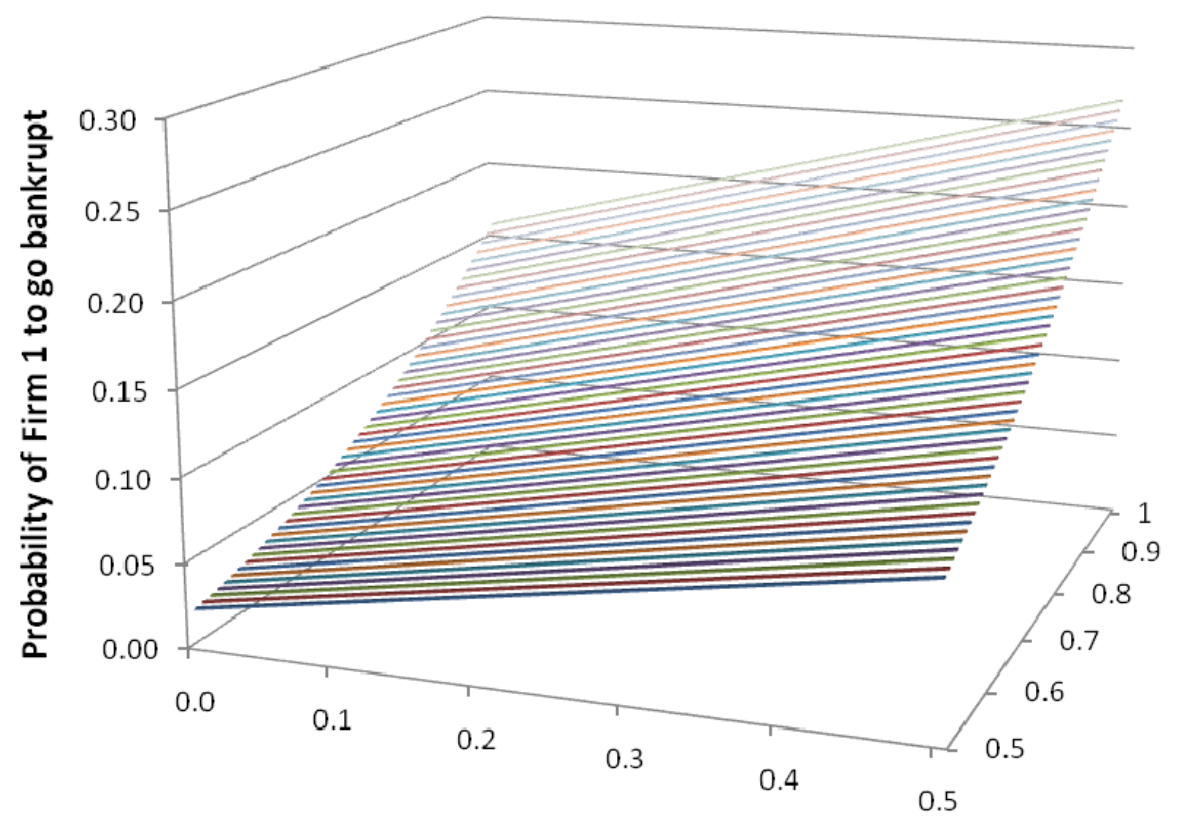

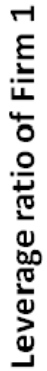

Probability of aggregate innovation 


\section{Figure 3. Effects of Aggregate Innovation and Economy State on Firm 1's Bankruptcy Risk}

The figure shows the probability of Firm 1 to go bankrupt, $P\left\{\left(C_{i}+A_{i}\right) K_{i} \varepsilon+\left[1-\gamma\left(A_{1}+A_{2}\right) K_{i}\right]<D_{i}\right\}$, for different values of the probability of aggregate innovation, $P_{1}+P_{2}$ (where the two firms have the same probability to innovate), and the expected state of the economy, $\mu_{\varepsilon}$. The remaining parameter values are set to: $K_{1}=1, D_{1}=1, C_{1}=0.5, \gamma=0.5$, and $\sigma_{\varepsilon}=1$.

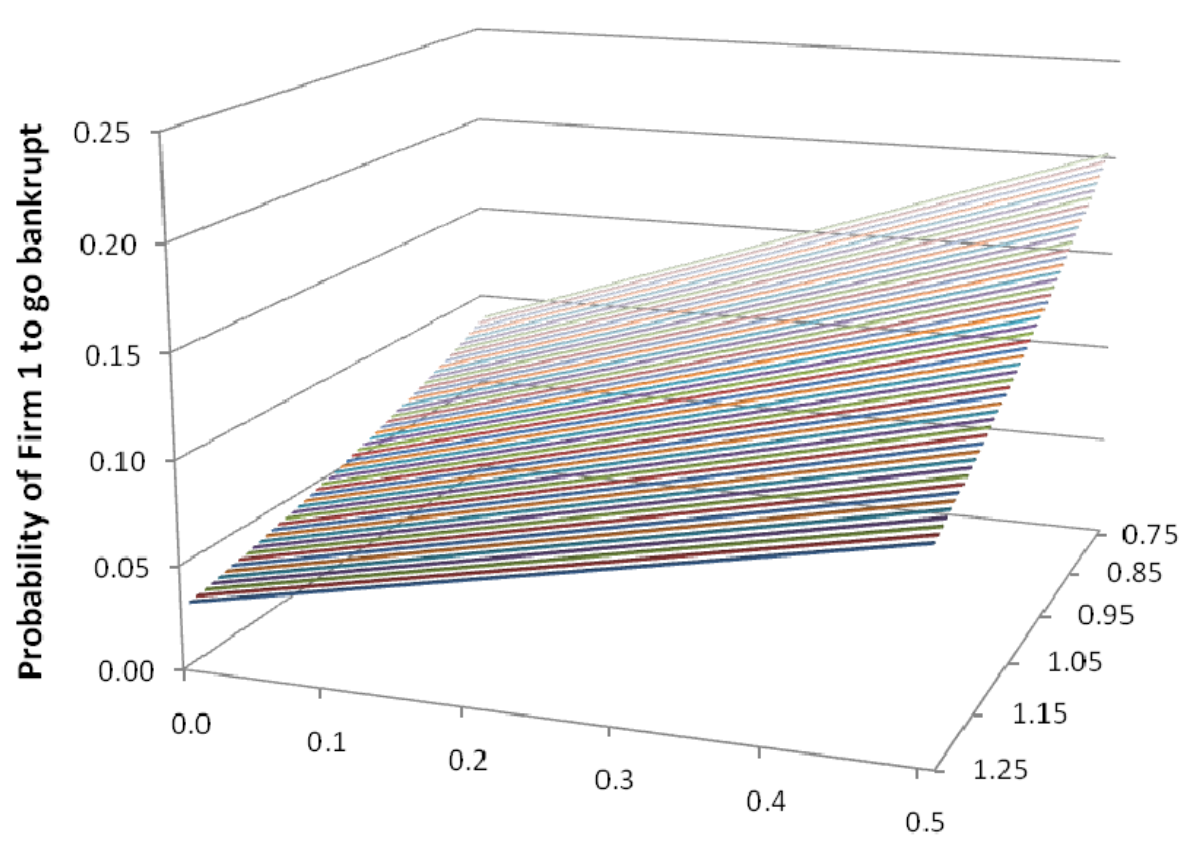

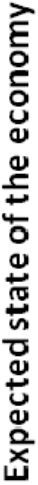

Probability of aggregate innovation 


\section{Figure 4. Technology-Related and Ordinary Bankruptcy Costs}

The figure displays the expected costs of technology-related and ordinary bankruptcies as defined in Section II.C. The parameter values used are $K_{1}=1, D_{1}=0.7, C_{1}=0.5, \gamma=0.5, \mu_{\varepsilon}=1, \sigma_{\varepsilon}=1$, and $P_{1}=P_{2}=0.5$, where Figures $4 \mathrm{a}$, 4b, and 4c, show the bankruptcy costs when $D_{1}, \mu_{\varepsilon}$, and $\sigma_{\varepsilon}$ vary.

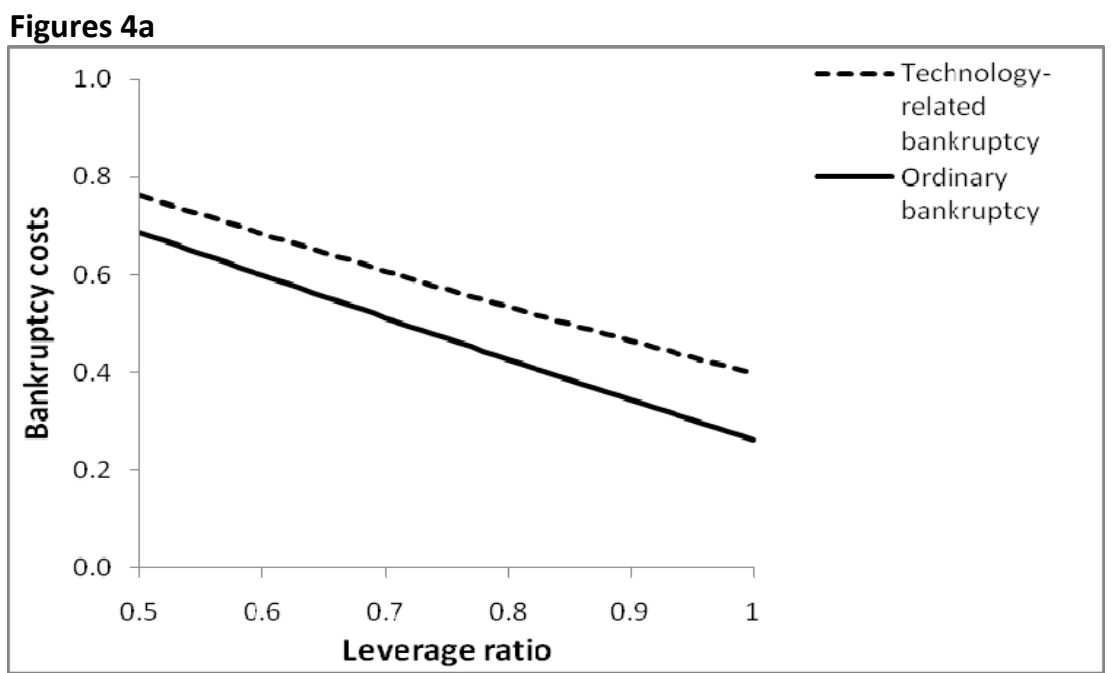

\section{Figure 4b}

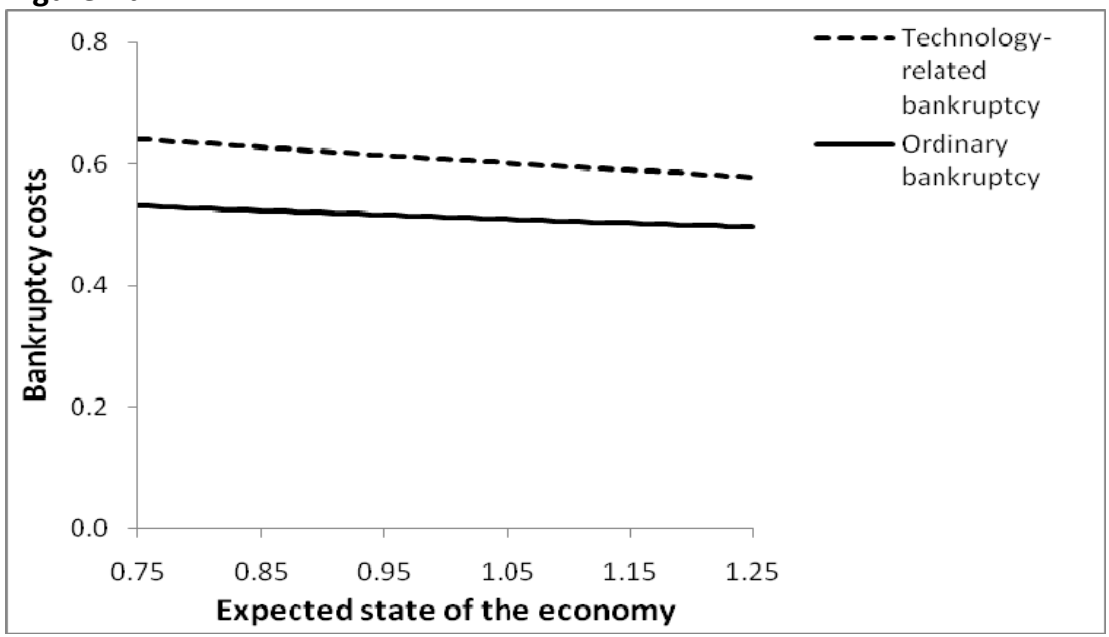

Figure 4c

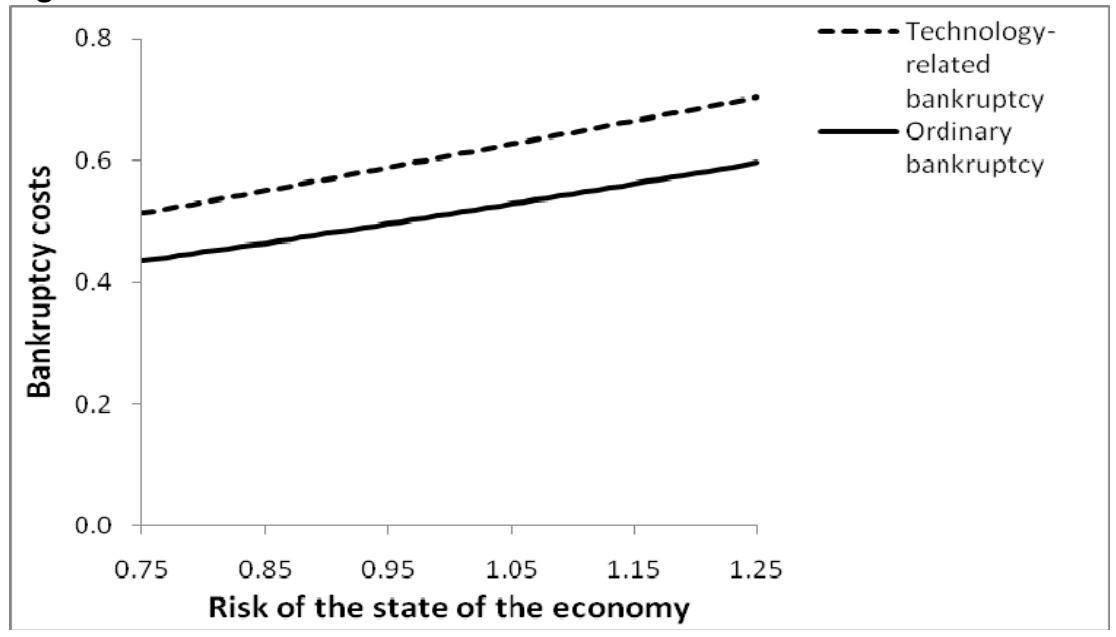




\section{Figure 5. Time Series Relation between the Change in Number of Patents and Future Bankruptcy Frequency in Technology-Intensive Industries}

The change in total number of patents is the difference between the number of patents issued in the current and previous years in technology-intensive industries (all 4-digit SIC industries in which at least $25 \%$ of the firms file successful patent applications, as listed in Table I). Bankruptcy frequency is the number of firms in technology-intensive industries that went bankrupt during the next three years, divided by the total number of firms in these industries.

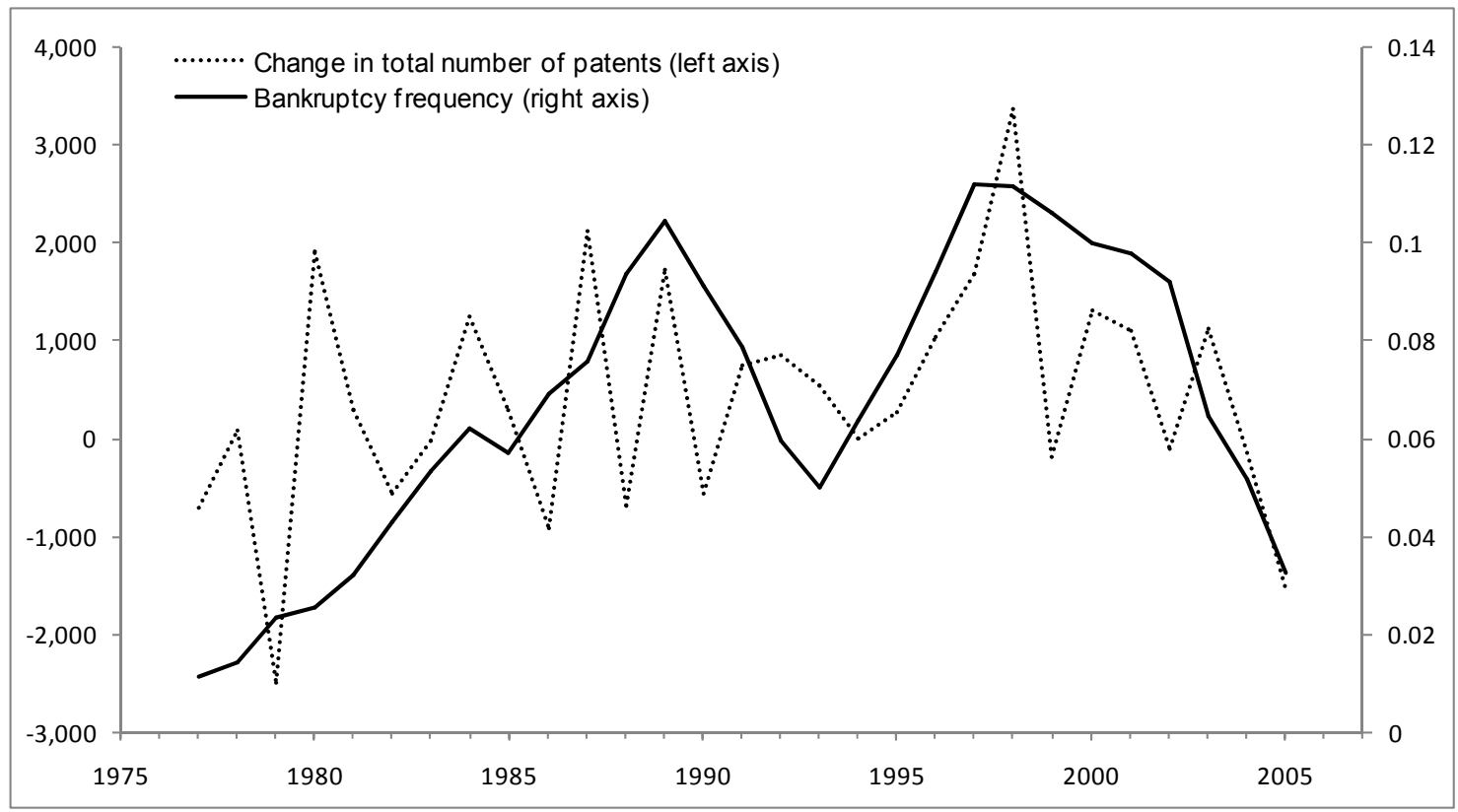




\section{Figure 6. Predictive Effects of Patent-Based and Other Measures on the Probability of Bankruptcy in Technology-Intensive Industries}

The sample contains firms in technology-intensive industries (all 4-digit SIC industries in which at least $25 \%$ of the firms file successful patent applications, as listed in Table I) over the period 1976-2005. The results are based on the logit regressions appearing in Table V: Bankruptcy indicator $=\alpha+\beta^{\prime} X+\varepsilon$, where $X$ is a set of bankruptcy predictors. The model's probability of bankruptcy is $P(B)=e^{\hat{\alpha}+\hat{\beta}^{\prime} x} /\left(1+e^{\hat{\alpha}+\hat{\beta}^{\prime} x}\right)$, and the economic effect of each predictor is defined by the change in $P(B)$ as a result of one standard deviation change in the predictor value from its mean. The bankruptcy predictors (as described in Table V) are: the patent-based measures, Firm PT-RD and Ind. PI (appear jointly in the regression), Z-score, credit rating, and KMV (appear separately in the regressions). The changes in $P(B)$ of all predictors are compared to the unconditional probability of bankruptcy, measured by the bankruptcy frequency in the sample.

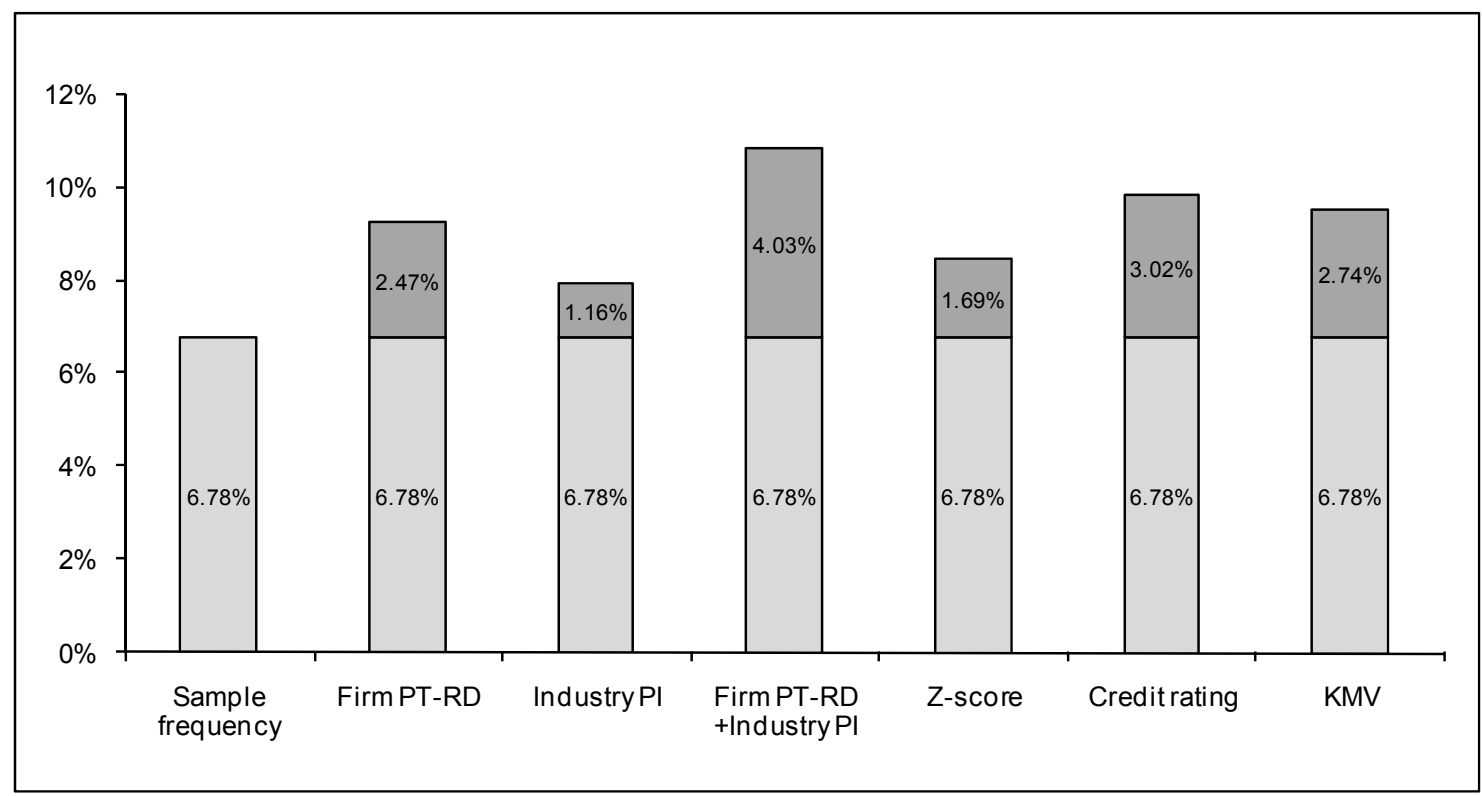




\section{Table I. Technology-Intensive Industries}

The list of 62 4-digit SIC industries in which at least $25 \%$ of the firms file successful patent applications during a calendar year over 1976-2005.

\begin{tabular}{|c|c|}
\hline Industry & $\%$ patent applications \\
\hline Aircraft \& Parts & $93.75 \%$ \\
\hline Electronic \& Other Electrical Equipment (No Computer Equip) & $76.74 \%$ \\
\hline Computer \& office Equipment & $65.32 \%$ \\
\hline Primary Production of Aluminum & $59.70 \%$ \\
\hline Motor Vehicles \& Passenger Car Bodies & $53.73 \%$ \\
\hline Chemicals \& Allied Products & $52.51 \%$ \\
\hline Papers \& Allied Products & $48.62 \%$ \\
\hline Plastic Material, Synth Resin/Rubber, Cellulos (No Glass) & $48.52 \%$ \\
\hline Guided Missiles \& Space Vehicles \& Parts & $45.70 \%$ \\
\hline Electronic Connectors & $45.67 \%$ \\
\hline Semiconductors \& Related Devices & $45.16 \%$ \\
\hline Heating Equip, Except Elec \& Warm Air; \& Plumbing Fixtures & $44.57 \%$ \\
\hline Aircraft & $44.53 \%$ \\
\hline Miscellaneous Chemical Products & $43.77 \%$ \\
\hline Office Machines, NEC & $42.22 \%$ \\
\hline Farm Machinery \& Equipment & $40.47 \%$ \\
\hline Office Furniture & $40.40 \%$ \\
\hline Miscellaneous Products of Petroleum \& Coal & $39.33 \%$ \\
\hline Lawn \& Garden Tractors \& Home Lawn \& Gardens Equip & $38.89 \%$ \\
\hline Plastic Materials, Synth Resins \& Nonvulcan Elastomers & $36.95 \%$ \\
\hline Auto Controls For Regulating Residential \& Comml Environments & $36.45 \%$ \\
\hline Construction Machinery \& Equip & $35.93 \%$ \\
\hline Rubber \& Plastics Footwear & $35.14 \%$ \\
\hline Soap, Detergents, Cleaning Preparations, Perfumes, Cosmetics & $34.78 \%$ \\
\hline Surgical \& Medical Instruments \& Apparatus & $34.05 \%$ \\
\hline Paints, Varnishes, Lacquers, Enamels \& Allied Prods & $33.44 \%$ \\
\hline Metalworkg Machinery \& Equipment & $33.41 \%$ \\
\hline Aircraft Parts \& Auxiliary Equipment, NEC & $33.33 \%$ \\
\hline Computer Storage Devices & $33.20 \%$ \\
\hline Motorcycles, Bicycles \& Parts & $32.81 \%$ \\
\hline Special Industry Machinery, NEC & $32.55 \%$ \\
\hline Power, Distribution \& Specialty Transformers & $32.37 \%$ \\
\hline Paper Mills & $32.13 \%$ \\
\hline Motor Vehicle Parts \& Accessories & $32.10 \%$ \\
\hline Laboratory Analytical Instruments & $32.08 \%$ \\
\hline Search, Detection, Navigation, Guidance, Aeronautical Sys & $31.98 \%$ \\
\hline Beverages & $31.87 \%$ \\
\hline Household Audio \& Video Equipment & $31.84 \%$ \\
\hline Greeting Cards & $31.34 \%$ \\
\hline Metal Cans & $31.29 \%$ \\
\hline Dolls \& Stuffed Toys & $30.77 \%$ \\
\hline Food and Kindred Products & $30.03 \%$ \\
\hline Switchgear \& Switchboard Apparatus & $29.53 \%$ \\
\hline Electronic Computers & $29.33 \%$ \\
\hline Engines \& Turbines & $28.90 \%$ \\
\hline General Industrial Machinery \& Equipment, NEC & $28.65 \%$ \\
\hline Household Appliances & $28.07 \%$ \\
\hline Industrial Process Furnaces \& Ovens & $28.04 \%$ \\
\hline Public Bldg \& Related Furniture & $27.70 \%$ \\
\hline Biological Products (No Diagnostic Substances) & $27.65 \%$ \\
\hline Grain Mill Products & $27.44 \%$ \\
\hline General Industrial Machinery \& Equipment & $27.43 \%$ \\
\hline Pharmaceutical Preparations & $26.90 \%$ \\
\hline Computer Peripheral Equipment, NEC & $26.84 \%$ \\
\hline Electric Housewares \& Fans & $26.59 \%$ \\
\hline Paperboard Mills & $26.55 \%$ \\
\hline Electromedical \& Electrotherapeutic Apparatus & $25.67 \%$ \\
\hline Instruments For Meas \& Testing of Electricity \& Elec Signals & $25.58 \%$ \\
\hline Air-Cond \& Warm Air Heatg Equip \& Comm \& Indl Refrig Equip & $25.46 \%$ \\
\hline Pumps \& Pumping Equipment & $25.35 \%$ \\
\hline Oil \& Gas Field Machinery \& Equipment & $25.28 \%$ \\
\hline Electronic Components \& Accessories & $25.00 \%$ \\
\hline
\end{tabular}




\section{Table II. Descriptive Statistics of Technology-Intensive Industries and Other Industries}

Technology-intensive industries include the 4-digit SIC industries in which the average percentage of firms filing successful patent applications during a calendar year is at least $25 \%$ (as listed in Table I). Other industries include the remaining 4-digit SIC codes. For all variables, observations outside the top and the bottom percentiles are excluded. The firm-specific variables are: size (in millions of dollars) is measured by the market value of equity, calculated by the stock price times the number of shares outstanding; market-tobook ratio is equity market value divided by equity book value; book leverage is the book value of debt divided by the book value of total assets; R\&D investment is measured as a fraction of the book value of total assets; Z-score is based on Altman's (1968) model for predicting bankruptcy; credit rating is the S\&P senior debt rating, taken from Compustat; and the KMV measure follows the Merton-based approach developed by Crosbie and Bohn (2002) for measuring default risk. The results are calculated over 19762005.

\begin{tabular}{lrrrrrrr}
\hline & \multicolumn{3}{c}{$\begin{array}{c}\text { Technology-intensive industries } \\
\text { (\% market cap }=30.4)\end{array}$} & \multicolumn{3}{c}{$\begin{array}{c}\text { Other industries } \\
\text { (\% market cap }=69.6)\end{array}$} \\
& Mean & Median & StdD & Mean & Median & StdD \\
\# patent applications per firm in a year & 15.25 & 0.00 & 59.65 & 1.87 & 0.00 & 21.24 \\
\# patent issues per firm in a year & 14.23 & 0.00 & 57.33 & 1.75 & 0.00 & 20.82 \\
\% firms apply for patents in a year & 32.95 & 0.00 & 47.00 & 7.17 & 0.00 & 25.79 \\
\% firms issue patents in a year & 31.16 & 0.00 & 46.32 & 6.65 & 0.00 & 24.91 \\
Size & $1,731.67$ & 101.02 & $9,503.16$ & 974.13 & 63.16 & $7,585.40$ \\
Market-to-book & 2.88 & 1.91 & 2.99 & 2.32 & 1.51 & 2.55 \\
Book leverage & 0.20 & 0.17 & 0.18 & 0.25 & 0.23 & 0.21 \\
R\&D investment & 0.10 & 0.05 & 0.14 & 0.03 & 0.00 & 0.08 \\
Z-score & 4.33 & 3.46 & 3.64 & 3.70 & 3.07 & 3.19 \\
Credit rating & 10.88 & 11.00 & 4.09 & 12.26 & 12.00 & 4.02 \\
KMV measure & 0.11 & 0.02 & 0.19 & 0.13 & 0.03 & 0.21 \\
\hline
\end{tabular}




\section{Table III. Time Series Regressions of Future Bankruptcy Frequency on Patent Issues in Technology-Intensive Industries and in the Entire Market}

The results are presented for a sample of technology-intensive industries, which are all 4-digit SIC industries in which at least $25 \%$ of the firms file successful patent applications (as listed in Table I), and for a sample of all industries. In Panel A the dependent is bankruptcy frequency, calculated by the number of firms that went bankrupt during the next three years in technology-intensive industries only (and in all industries), divided by the total number of firms in technology-intensive industries only (and in all industries). The primary independent variable is the total number of patents (in thousands) issued in the past one year and in the past three years. The control variables are the interest rate, measured by the nominal return on 1-month Treasury bills; the default spread, estimated by the yield spread between longterm Baa- and Aaa-rated securities; and the NBER recession dummy variable. Panel B shows similar regressions where the independent variable is the annual change in number of patents. The table shows regression coefficients and $p$-values, based on Newey-West standard errors, for a sample of 30 years over 1976-2005.

\begin{tabular}{|c|c|c|c|c|c|c|c|}
\hline \multicolumn{8}{|c|}{ Panel A: Total number of patents } \\
\hline \multicolumn{2}{|c|}{ Patent issues in the past year } & Intercept & \# patents & Interest & Default & Recession & R-square \\
\hline \multirow[t]{2}{*}{$\begin{array}{l}\text { Tech. intensive } \\
\text { industries }\end{array}$} & $\begin{array}{l}\text { Coefficient } \\
\text { P-value }\end{array}$ & $\begin{array}{l}0.01825 \\
(0.336)\end{array}$ & $\begin{array}{l}0.00349 \\
(0.007)\end{array}$ & & & & 0.312 \\
\hline & & $\begin{array}{l}0.00715 \\
(0.879)\end{array}$ & $\begin{array}{l}0.00429 \\
(0.037)\end{array}$ & $\begin{array}{l}0.45151 \\
(0.259)\end{array}$ & $\begin{array}{l}-2.63192 \\
(0.264)\end{array}$ & $\begin{array}{l}0.00987 \\
(0.674)\end{array}$ & 0.314 \\
\hline \multirow[t]{2}{*}{ All industries } & $\begin{array}{l}\text { Coefficient } \\
\text { P-value }\end{array}$ & $\begin{array}{l}0.03693 \\
(0.292)\end{array}$ & $\begin{array}{l}0.00249 \\
(0.118)\end{array}$ & & & & 0.113 \\
\hline & & $\begin{array}{l}0.03803 \\
(0.617)\end{array}$ & $\begin{array}{l}0.00307 \\
(0.204)\end{array}$ & $\begin{array}{l}0.59870 \\
(0.318)\end{array}$ & $\begin{array}{l}-4.69405 \\
(0.184)\end{array}$ & $\begin{array}{l}0.01192 \\
(0.733)\end{array}$ & 0.127 \\
\hline \multicolumn{2}{|c|}{ Patent issues in the past 3 years } & Intercept & \# patents & Interest & Default & Recession & R-square \\
\hline \multirow[t]{2}{*}{$\begin{array}{l}\text { Tech. intensive } \\
\text { industries }\end{array}$} & $\begin{array}{l}\text { Coefficient } \\
\text { P-value }\end{array}$ & $\begin{array}{l}0.04625 \\
(0.002)\end{array}$ & $\begin{array}{l}0.00049 \\
(0.068)\end{array}$ & & & & 0.167 \\
\hline & & $\begin{array}{l}0.08341 \\
(0.050)\end{array}$ & $\begin{array}{l}0.00026 \\
(0.569)\end{array}$ & $\begin{array}{l}0.06016 \\
(0.889)\end{array}$ & $\begin{array}{l}-2.88226 \\
(0.217)\end{array}$ & $\begin{array}{l}0.01935 \\
(0.401)\end{array}$ & 0.192 \\
\hline \multirow[t]{2}{*}{ All industries } & $\begin{array}{l}\text { Coefficient } \\
\text { P-value }\end{array}$ & $\begin{array}{l}0.07178 \\
(0.004)\end{array}$ & $\begin{array}{l}0.00029 \\
(0.321)\end{array}$ & & & & 0.031 \\
\hline & & $\begin{array}{l}0.12312 \\
(0.054)\end{array}$ & $\begin{array}{l}0.00012 \\
(0.809)\end{array}$ & $\begin{array}{l}0.17774 \\
(0.774)\end{array}$ & $\begin{array}{l}-4.59797 \\
(0.180)\end{array}$ & $\begin{array}{l}0.02003 \\
(0.549)\end{array}$ & 0.076 \\
\hline \multicolumn{8}{|c|}{ Panel B: Change in number of patents } \\
\hline \multicolumn{2}{|c|}{ Patent issues in the past year } & Intercept & $\Delta \#$ patents & Interest & Default & Recession & R-square \\
\hline \multirow[t]{2}{*}{$\begin{array}{l}\text { Tech. intensive } \\
\text { industries }\end{array}$} & $\begin{array}{l}\text { Coefficient } \\
\text { P-value }\end{array}$ & $\begin{array}{l}0.06312 \\
(0.336)\end{array}$ & $\begin{array}{l}0.01115 \\
(0.012)\end{array}$ & & & & 0.187 \\
\hline & & $\begin{array}{l}0.09074 \\
(0.879)\end{array}$ & $\begin{array}{l}0.01045 \\
(0.015)\end{array}$ & $\begin{array}{l}-0.08354 \\
(0.690)\end{array}$ & $\begin{array}{l}-2.34366 \\
(0.206)\end{array}$ & $\begin{array}{l}0.02798 \\
(0.029)\end{array}$ & 0.384 \\
\hline \multirow[t]{2}{*}{ All industries } & $\begin{array}{l}\text { Coefficient } \\
\text { P-value }\end{array}$ & $\begin{array}{l}0.08654 \\
(0.000)\end{array}$ & $\begin{array}{l}0.00942 \\
(0.015)\end{array}$ & & & & 0.165 \\
\hline & & $\begin{array}{l}0.11954 \\
(0.000)\end{array}$ & $\begin{array}{l}0.00836 \\
(0.037)\end{array}$ & $\begin{array}{l}0.09210 \\
(0.781)\end{array}$ & $\begin{array}{l}-3.72838 \\
(0.213)\end{array}$ & $\begin{array}{l}0.02333 \\
(0.229)\end{array}$ & 0.285 \\
\hline \multicolumn{2}{|c|}{ Patent issues in the past 3 years } & Intercept & $\Delta \#$ patents & Interest & Default & Recession & R-square \\
\hline \multirow[t]{2}{*}{$\begin{array}{l}\text { Tech. intensive } \\
\text { industries }\end{array}$} & $\begin{array}{l}\text { Coefficient } \\
\text { P-value }\end{array}$ & $\begin{array}{l}0.05576 \\
(0.000)\end{array}$ & $\begin{array}{l}0.00574 \\
(0.000)\end{array}$ & & & & 0.488 \\
\hline & & $\begin{array}{l}0.07844 \\
(0.000)\end{array}$ & $\begin{array}{l}0.00496 \\
(0.007)\end{array}$ & $\begin{array}{l}0.27293 \\
(0.183)\end{array}$ & $\begin{array}{l}-3.56675 \\
(0.003)\end{array}$ & $\begin{array}{l}0.02017 \\
(0.052)\end{array}$ & 0.647 \\
\hline \multirow[t]{2}{*}{ All industries } & $\begin{array}{l}\text { Coefficient } \\
\text { P-value }\end{array}$ & $\begin{array}{l}0.07700 \\
(0.000)\end{array}$ & $\begin{array}{l}0.00533 \\
(0.000)\end{array}$ & & & & 0.462 \\
\hline & & $\begin{array}{l}0.09591 \\
(0.000)\end{array}$ & $\begin{array}{l}0.00536 \\
(0.001)\end{array}$ & $\begin{array}{l}0.60705 \\
(0.038)\end{array}$ & $\begin{array}{l}-5.19626 \\
(0.006)\end{array}$ & $\begin{array}{l}0.01398 \\
(0.362)\end{array}$ & 0.635 \\
\hline
\end{tabular}




\section{Table IV. Industrywide Regressions of Future Bankruptcy Frequency on Patent Issues in Technology-Intensive Industries}

The sample contains all 4-digit SIC industries in which at least $25 \%$ of the firms file successful patent applications (as listed in Table I). In Panel A the dependent variable is the number of firms in the industry that have not issued patents in the past year and went bankrupt during the next three years, divided by the number of firms that have not issued patents in the past year. The primary independent variable is the number of patents (in thousands) issued in the industry in the past year; as the number of patents has very large outliers, observations with more than 100 patents were set to 100 . The control variables are the mean $Z$-score, the proportion of firms with speculative-grade bonds (rating of $\mathrm{BB}+$ or lower), and the mean KMV measure, all among the firms in the industry that have not issued patents in the past year. Panel B shows similar results where patents are considered in the past three years. The table shows regression coefficients and $p$-values, based on Newey-West standard errors modified for panel data, for a sample of industry-years over 1976-2005.

\begin{tabular}{|c|c|c|c|c|c|c|c|}
\hline \multicolumn{8}{|c|}{ Panel A: Patent issues in the past year } \\
\hline Bankruptcy freq & Intercept & \# patents & Mean Z & Spec. rating & Mean KMV & \# Obs & R-square \\
\hline \multirow[t]{6}{*}{$\begin{array}{l}\text { Coefficient } \\
\text { P-value }\end{array}$} & $\begin{array}{l}0.05760 \\
(0.000)\end{array}$ & $\begin{array}{l}0.22350 \\
(0.000)\end{array}$ & & & & 1,812 & 0.018 \\
\hline & $\begin{array}{l}0.06279 \\
(0.000)\end{array}$ & $\begin{array}{l}0.23202 \\
(0.000)\end{array}$ & $\begin{array}{l}-0.00306 \\
(0.002)\end{array}$ & & & 1,822 & 0.026 \\
\hline & $\begin{array}{l}0.05920 \\
(0.000)\end{array}$ & $\begin{array}{l}0.14102 \\
(0.012)\end{array}$ & & $\begin{array}{l}0.03262 \\
(0.007)\end{array}$ & & 747 & 0.024 \\
\hline & $\begin{array}{l}0.04228 \\
(0.000)\end{array}$ & $\begin{array}{l}0.23641 \\
(0.000)\end{array}$ & & & $\begin{array}{l}0.13518 \\
(0.000)\end{array}$ & 1,344 & 0.045 \\
\hline & $\begin{array}{l}0.06683 \\
(0.000)\end{array}$ & & $\begin{array}{l}-0.00351 \\
(0.007)\end{array}$ & $\begin{array}{l}0.01834 \\
(0.197)\end{array}$ & $\begin{array}{l}0.25039 \\
(0.000)\end{array}$ & 474 & 0.075 \\
\hline & $\begin{array}{l}0.05341 \\
(0.000)\end{array}$ & $\begin{array}{l}0.15944 \\
(0.048)\end{array}$ & $\begin{array}{l}-0.00389 \\
(0.004)\end{array}$ & $\begin{array}{l}0.01684 \\
(0.226)\end{array}$ & $\begin{array}{l}0.22832 \\
(0.000)\end{array}$ & 474 & 0.086 \\
\hline \multicolumn{8}{|c|}{ Panel B: Patent issues in the past 3 years } \\
\hline Bankruptcy freq & Intercept & \# patents & Mean Z & Spec. rating & Mean KMV & \# Obs & R-square \\
\hline \multirow[t]{6}{*}{$\begin{array}{l}\text { Coefficient } \\
\text { P-value }\end{array}$} & $\begin{array}{l}0.04279 \\
(0.000)\end{array}$ & $\begin{array}{l}0.22625 \\
(0.000)\end{array}$ & & & & 1,722 & 0.014 \\
\hline & $\begin{array}{l}0.04972 \\
(0.000)\end{array}$ & $\begin{array}{l}0.22940 \\
(0.000)\end{array}$ & $\begin{array}{l}-0.00359 \\
(0.000)\end{array}$ & & & 1,722 & 0.028 \\
\hline & $\begin{array}{l}0.03869 \\
(0.002)\end{array}$ & $\begin{array}{l}0.17732 \\
(0.034)\end{array}$ & & $\begin{array}{l}0.04454 \\
(0.001)\end{array}$ & & 657 & 0.034 \\
\hline & $\begin{array}{l}0.02659 \\
(0.005)\end{array}$ & $\begin{array}{l}0.24538 \\
(0.000)\end{array}$ & & & $\begin{array}{l}0.13991 \\
(0.000)\end{array}$ & 1,233 & 0.041 \\
\hline & $\begin{array}{l}0.04969 \\
(0.000)\end{array}$ & & $\begin{array}{l}-0.00250 \\
(0.018)\end{array}$ & $\begin{array}{l}0.03590 \\
(0.023)\end{array}$ & $\begin{array}{l}0.24949 \\
(0.000)\end{array}$ & 422 & 0.083 \\
\hline & $\begin{array}{l}0.02243 \\
(0.171)\end{array}$ & $\begin{array}{l}0.20423 \\
(0.077)\end{array}$ & $\begin{array}{l}-0.00273 \\
(0.010)\end{array}$ & $\begin{array}{l}0.03303 \\
(0.044)\end{array}$ & $\begin{array}{l}0.23487 \\
(0.000)\end{array}$ & 422 & 0.095 \\
\hline
\end{tabular}




\section{Table V. Firm-Specific Logit Regressions of the Likelihood of Bankruptcy on the Firm's Relative Innovative Strength and the Industry's Patent Competition in Technology-Intensive Industries}

The sample contains firms in technology-intensive industries (all 4-digit SIC industries in which at least $25 \%$ of the firms file successful patent applications, as listed in Table I). In Panel A the dependent variable (bankruptcy indicator) equals one if the firm went bankrupt during the next three years, and zero otherwise. The primary independent variables are: (i) Firm PT-RD, which is the ratio of the number of patents issued by the firm in the past year to the total number of patents issued in the industry in the past year minus the ratio the firm's average R\&D expenditures in the past three years to its equity market value; and (ii) Ind. PI, which is the total number of patent applications in the industry in the year divided by the industry size (the sum of equity market values of all firms in the industry). The control variables are the firm's Z-score; a credit rating dummy variable that equals one if the rating is BB+ or lower (speculative grade), and zero otherwise (investment grade); the KMV measure (as described in Table III); and industry dummies and year dummies to control for fixed effects. Panel B shows similar regressions where patents are considered in the past three years. The table shows logit regression coefficients and $p$-values, based on standard errors clustered by individual firms, for a sample of firm-years over the period 1976-2005.

\begin{tabular}{|c|c|c|c|c|c|c|c|}
\hline \multicolumn{8}{|c|}{ Panel A: Patent issues in the past year } \\
\hline & Intercept & Firm PT-RD & Ind. PI & Z-score & Credit rating & KMV & \# Obs \\
\hline \multirow[t]{4}{*}{$\begin{array}{l}\text { Coefficient } \\
\text { P-value }\end{array}$} & $\begin{array}{l}-4.39508 \\
(0.000)\end{array}$ & $\begin{array}{l}-0.92881 \\
(0.000)\end{array}$ & $\begin{array}{l}2.95071 \\
(0.000)\end{array}$ & & & & 30,390 \\
\hline & $\begin{array}{l}-4.48984 \\
(0.000)\end{array}$ & $\begin{array}{l}-0.87529 \\
(0.000)\end{array}$ & $\begin{array}{l}2.90271 \\
(0.000)\end{array}$ & $\begin{array}{l}-0.00823 \\
(0.000)\end{array}$ & & & 30,390 \\
\hline & $\begin{array}{l}-4.27075 \\
(0.000)\end{array}$ & $\begin{array}{l}-1.31390 \\
(0.001)\end{array}$ & $\begin{array}{l}4.94382 \\
(0.061)\end{array}$ & & $\begin{array}{l}2.10372 \\
(0.000)\end{array}$ & & 4,463 \\
\hline & $\begin{array}{l}-2.18577 \\
(0.003)\end{array}$ & $\begin{array}{l}-0.94304 \\
(0.000)\end{array}$ & $\begin{array}{l}3.38382 \\
(0.000)\end{array}$ & & & $\begin{array}{l}2.12480 \\
(0.000)\end{array}$ & 10,250 \\
\hline \multicolumn{8}{|c|}{ Panel B: Patent issues in the past 3 years } \\
\hline \multirow{5}{*}{$\begin{array}{l}\text { Coefficient } \\
\text { P-value }\end{array}$} & Intercept & Firm PT-RD & Ind. PI & Z-score & Credit rating & KMV & \# Obs \\
\hline & $\begin{array}{l}-3.27245 \\
(0.000)\end{array}$ & $\begin{array}{l}-0.81128 \\
(0.000)\end{array}$ & $\begin{array}{l}2.79539 \\
(0.000)\end{array}$ & & & & 27,184 \\
\hline & $\begin{array}{l}-3.46008 \\
(0.000)\end{array}$ & $\begin{array}{l}-0.73690 \\
(0.000)\end{array}$ & $\begin{array}{l}2.73957 \\
(0.000)\end{array}$ & $\begin{array}{l}-0.00928 \\
(0.000)\end{array}$ & & & 27,184 \\
\hline & $\begin{array}{l}-2.33830 \\
(0.035)\end{array}$ & $\begin{array}{l}-1.46495 \\
(0.001)\end{array}$ & $\begin{array}{l}4.86993 \\
(0.075)\end{array}$ & & $\begin{array}{l}2.16623 \\
(0.000)\end{array}$ & & 4,370 \\
\hline & $\begin{array}{l}-1.91989 \\
(0.013)\end{array}$ & $\begin{array}{l}-0.70738 \\
(0.000)\end{array}$ & $\begin{array}{l}2.92281 \\
(0.006)\end{array}$ & & & $\begin{array}{l}2.37499 \\
(0.000)\end{array}$ & 9,066 \\
\hline
\end{tabular}




\section{Table VI. Two-Stage Firm-Specific Probit Regressions of the Likelihood of Bankruptcy on the Firm's Relative Innovative Strength and the Industry's Patent Competition in Technology-Intensive Industries}

The sample contains firms in technology-intensive industries (all 4-digit SIC industries in which at least $25 \%$ of the firms file successful patent applications, as listed in Table I). The table shows the results of a second-stage probit regression of the following two-stage regression procedure. In the first stage we run a linear regression of Firm PT-RD (the ratio of the number of patents issued by the firm in the past year to the total number of patents issued in the industry in the past year minus the ratio the firm's average R\&D expenditures in the past three years to its equity market value) on two instrumental variables: the percentage of all public firms in a specific industry that have a patent record over the past five years, and the average $R \& D$ cost of each patent in a specific industry over the past five years. This regression generates the predicted Firm PT-RD. In the second stage we run a probit regression, where the dependent variable is the bankruptcy dummy (equals one if the firm went bankrupt in the following three years, and zero otherwise) and the primary independent variables are the predicted Firm PT-RD (P_Firm PT-RD), and Ind. PI, which is the total number of patent applications in the industry in the year divided by the industry size. The control variables are the firm's Z-score; a credit rating dummy variable that equals one if the rating is $\mathrm{BB}^{+}$or lower (speculative grade), and zero otherwise (investment grade); the KMV measure (as described in Table III), industry dummies and year dummies. Panels A and B present the results where patents are considered in the past year and three years, respectively. The table shows coefficients and $p$ values, based on standard errors clustered by individual firms, for a sample of firm-years over the period 1976-2005.

\begin{tabular}{|c|c|c|c|c|c|c|c|}
\hline \multicolumn{8}{|c|}{ Panel A: Patent issues in the past year } \\
\hline & Intercept & P_Firm PT-RD & Ind. PI & Z-score & Credit rating & KMV & \# Obs \\
\hline \multirow[t]{4}{*}{$\begin{array}{c}\text { Coefficient } \\
\text { P-value }\end{array}$} & $\begin{array}{l}-3.10468 \\
(0.000)\end{array}$ & $\begin{array}{l}-1.85595 \\
(0.000)\end{array}$ & $\begin{array}{l}1.12292 \\
(0.000)\end{array}$ & & & & 30,390 \\
\hline & $\begin{array}{l}-3.10095 \\
(0.000)\end{array}$ & $\begin{array}{l}-1.86429 \\
(0.000)\end{array}$ & $\begin{array}{l}1.08449 \\
(0.000)\end{array}$ & $\begin{array}{l}-0.00315 \\
(0.000)\end{array}$ & & & 30,390 \\
\hline & $\begin{array}{l}-2.00639 \\
(0.000)\end{array}$ & $\begin{array}{l}-2.31889 \\
(0.000)\end{array}$ & $\begin{array}{l}0.45102 \\
(0.092)\end{array}$ & & $\begin{array}{l}0.20456 \\
(0.044)\end{array}$ & & 4,463 \\
\hline & $\begin{array}{l}-0.72182 \\
(0.031)\end{array}$ & $\begin{array}{l}-2.28292 \\
(0.000)\end{array}$ & $\begin{array}{l}0.39295 \\
(0.052)\end{array}$ & & & $\begin{array}{l}0.24416 \\
(0.043)\end{array}$ & 10,250 \\
\hline \multicolumn{8}{|c|}{ Panel B: Patent issues in the past 3 years } \\
\hline & Intercept & P_Firm PT-RD & Ind. PI & Z-score & Credit rating & KMV & \# Obs \\
\hline \multirow[t]{4}{*}{$\begin{array}{c}\text { Coefficient } \\
\text { P-value }\end{array}$} & $\begin{array}{l}0.37473 \\
(0.205)\end{array}$ & $\begin{array}{l}-2.38133 \\
(0.000)\end{array}$ & $\begin{array}{l}0.43386 \\
(0.004)\end{array}$ & & & & 27,184 \\
\hline & $\begin{array}{l}0.26429 \\
(0.379)\end{array}$ & $\begin{array}{l}-2.38111 \\
(0.000)\end{array}$ & $\begin{array}{l}0.37815 \\
(0.011)\end{array}$ & $\begin{array}{l}-0.00134 \\
(0.008)\end{array}$ & & & 27,184 \\
\hline & $\begin{array}{l}-0.01444 \\
(0.943)\end{array}$ & $\begin{array}{l}-2.46759 \\
(0.000)\end{array}$ & $\begin{array}{l}0.40944 \\
(0.104)\end{array}$ & & $\begin{array}{l}0.19753 \\
(0.048)\end{array}$ & & 4,370 \\
\hline & $\begin{array}{l}0.41813 \\
(0.109)\end{array}$ & $\begin{array}{l}-2.39408 \\
(0.000)\end{array}$ & $\begin{array}{c}0.28597 \\
(0.045)\end{array}$ & & & $\begin{array}{l}0.23070 \\
(0.028)\end{array}$ & 9,066 \\
\hline
\end{tabular}




\section{Table VII. The Effects of Business Cycle and Industry Growth on Bankruptcy in Technology-Intensive Industries}

The upper box in Panel A shows industry-year linear regressions. The dependent variable is the bankruptcy frequency in the industry (\# of bankruptcies/\# firms) in both the current year and the next three years. The independent variables are: RC is the NBER recession dummy variable; PDI is a dummy variable that equals one if the industry is technology-intensive (all 4-digit SIC industries in which at least $25 \%$ of the firms file successful patent applications, as listed in Table I), and zero otherwise; and Pct Ap is the average percentage of firms in the industry that file successful patent applications during a calendar year. The lower box in Panel A shows firm-year logit regressions. The dependent dummy variable equals one if the firm went bankrupt, in both the current year and the next three years, and the independent variables are as in the upper box. Panel B shows similar regressions to Panel A, where replacing the recession dummy variable with the industry growth (IG), defined as the annual percentage change in the total revenues in the industry minus the annual percentage change in the total revenues in all industries. The table shows regression coefficients and $p$-values for a sample of all industries over 1976-2005. The standard errors are clustered by industries for industry-level regressions and by individual firms for firm-level regressions.

Panel A: Business cycle

\begin{tabular}{|c|c|c|c|c|c|c|}
\hline \multicolumn{7}{|c|}{ Panel A: Business cycle } \\
\hline \multicolumn{7}{|c|}{ Industry-level linear regression (\# Obs=12,707) } \\
\hline Bank_freq in the current year & Intercept & $\mathrm{RC}$ & RC*PDI & Intercept & $\mathrm{RC}$ & $\mathrm{RC}^{*}$ Pct Ap \\
\hline $\begin{array}{l}\text { Coefficient } \\
\text { P-value }\end{array}$ & $\begin{array}{l}0.02522 \\
(0.000)\end{array}$ & $\begin{array}{l}0.00978 \\
(0.000)\end{array}$ & $\begin{array}{l}-0.01079 \\
(0.015)\end{array}$ & $\begin{array}{l}0.02522 \\
(0.000)\end{array}$ & $\begin{array}{l}0.01066 \\
(0.000)\end{array}$ & $\begin{array}{l}-0.02372 \\
(0.058)\end{array}$ \\
\hline \multicolumn{7}{|l|}{ Bank_freq in the next 3 years } \\
\hline $\begin{array}{l}\text { Coefficient } \\
\text { P-value }\end{array}$ & $\begin{array}{l}0.09047 \\
(0.000)\end{array}$ & $\begin{array}{l}0.01038 \\
(0.023)\end{array}$ & $\begin{array}{l}-0.03215 \\
(0.000)\end{array}$ & $\begin{array}{l}0.09047 \\
(0.000)\end{array}$ & $\begin{array}{l}0.01372 \\
(0.009)\end{array}$ & $\begin{array}{l}-0.07780 \\
(0.002)\end{array}$ \\
\hline \multicolumn{7}{|c|}{ Firm-level logit regression (\# Obs=190,507) } \\
\hline Bankruptcy in the current year & Intercept & $\mathrm{RC}$ & RC*PDI & Intercept & $\mathrm{RC}$ & RC*Pct Ap \\
\hline $\begin{array}{l}\text { Coefficient } \\
\text { P-value }\end{array}$ & $\begin{array}{l}-3.76902 \\
(0.000)\end{array}$ & $\begin{array}{l}0.44970 \\
(0.000)\end{array}$ & $\begin{array}{l}-0.26764 \\
(0.011)\end{array}$ & $\begin{array}{l}-3.76902 \\
(0.000)\end{array}$ & $\begin{array}{l}0.41196 \\
(0.000)\end{array}$ & $\begin{array}{l}0.00294 \\
(0.991)\end{array}$ \\
\hline \multicolumn{7}{|l|}{ Bankruptcy in the next 3 years } \\
\hline $\begin{array}{l}\text { Coefficient } \\
\text { P-value }\end{array}$ & $\begin{array}{l}-2.38202 \\
(0.000)\end{array}$ & $\begin{array}{l}0.09806 \\
(0.000)\end{array}$ & $\begin{array}{l}-0.14742 \\
(0.059)\end{array}$ & $\begin{array}{l}-2.38202 \\
(0.000)\end{array}$ & $\begin{array}{l}0.07668 \\
(0.013)\end{array}$ & $\begin{array}{l}-0.00427 \\
(0.983)\end{array}$ \\
\hline \multicolumn{7}{|c|}{ Panel B: Industry growth } \\
\hline \multicolumn{7}{|c|}{ Industry-level linear regression (\# Obs=12,295) } \\
\hline Bank_freq in the current year & Intercept & IG & IG*PDI & Intercept & IG & $I G^{*} P c t A p$ \\
\hline $\begin{array}{c}\text { Coefficient } \\
\text { P-value }\end{array}$ & $\begin{array}{l}0.02588 \\
(0.000)\end{array}$ & $\begin{array}{l}-0.02138 \\
(0.000)\end{array}$ & $\begin{array}{l}0.01874 \\
(0.008)\end{array}$ & $\begin{array}{l}0.02589 \\
(0.000)\end{array}$ & $\begin{array}{l}-0.02175 \\
(0.000)\end{array}$ & $\begin{array}{l}0.02715 \\
(0.315)\end{array}$ \\
\hline \multicolumn{7}{|l|}{ Bank_freq in the next 3 years } \\
\hline $\begin{array}{l}\text { Coefficient } \\
\text { P-value }\end{array}$ & $\begin{array}{l}0.08811 \\
(0.000)\end{array}$ & $\begin{array}{l}-0.02893 \\
(0.000)\end{array}$ & $\begin{array}{l}0.03514 \\
(0.070)\end{array}$ & $\begin{array}{l}0.08807 \\
(0.000)\end{array}$ & $\begin{array}{l}-0.02690 \\
(0.003)\end{array}$ & $\begin{array}{l}0.01476 \\
(0.799)\end{array}$ \\
\hline \multicolumn{7}{|c|}{ Firm-level logit regression (\# Obs=188,178) } \\
\hline Bankruptcy in the current year & Intercept & IG & IG*PDI & Intercept & IG & $I G^{*} P c t A p$ \\
\hline $\begin{array}{l}\text { Coefficient } \\
\text { P-value }\end{array}$ & $\begin{array}{l}-3.69000 \\
(0.000)\end{array}$ & $\begin{array}{l}-0.75450 \\
(0.000)\end{array}$ & $\begin{array}{l}0.74598 \\
(0.000)\end{array}$ & $\begin{array}{l}-3.68822 \\
(0.000)\end{array}$ & $\begin{array}{l}-0.81599 \\
(0.000)\end{array}$ & $\begin{array}{l}1.70774 \\
(0.003)\end{array}$ \\
\hline \multicolumn{7}{|l|}{ Bankruptcy in the next 3 years } \\
\hline $\begin{array}{l}\text { Coefficient } \\
\text { P-value }\end{array}$ & $\begin{array}{l}-2.38590 \\
(0.000)\end{array}$ & $\begin{array}{l}-0.22667 \\
(0.000)\end{array}$ & $\begin{array}{c}0.28190 \\
(0.039)\end{array}$ & $\begin{array}{l}-2.38509 \\
(0.000)\end{array}$ & $\begin{array}{l}-0.27992 \\
(0.000)\end{array}$ & $\begin{array}{l}1.06909 \\
(0.004)\end{array}$ \\
\hline
\end{tabular}




\section{Table VIII. Indirect Bankruptcy Costs in Technology-Intensive Industries}

The table compares indirect bankruptcy costs of technology-related and ordinary bankruptcies. Technology-related bankruptcies contain all bankrupt firms in the technology-intensive industries (the 4digit SIC industries in which at least $25 \%$ of the firms file successful patent applications, as listed in Table I) that did not issue patents in the three years prior to the bankruptcy, while during that period other firms in the industry issued patents. We use two measures of bankruptcy costs: the abnormal earnings during the three years prior to bankruptcy scaled by asset book value, based on Altman's (1984) method; and the cumulative stock return in the three years prior to bankruptcy. The table presents the means and medians of the two measures, at both raw data (the actual bankruptcy costs), and industry adjusted data, which is the difference between the actual cost and the industry median; and the two-sided $p$-values of the difference between the means (T-test) and the medians (Wilcoxon-Mann-Whitney test) over 1976-2005.

\begin{tabular}{|c|c|c|c|c|c|c|c|c|c|}
\hline & & \multicolumn{3}{|c|}{$\begin{array}{l}\text { Technology-related } \\
\text { bankruptcies }\end{array}$} & \multicolumn{3}{|c|}{$\begin{array}{c}\text { Ordinary } \\
\text { bankruptcies }\end{array}$} & \multicolumn{2}{|c|}{ P-value of difference } \\
\hline & & \# Obs & Mean & Median & \# Obs & Mean & Median & Means & Medians \\
\hline \multirow[t]{2}{*}{ Abnormal earnings } & Raw data & 57 & -0.281 & -0.256 & 481 & -0.172 & -0.162 & $(0.178)$ & $(0.069)$ \\
\hline & Ind. adjusted & 57 & -0.236 & -0.189 & 486 & -0.124 & -0.098 & $(0.141)$ & $(0.067)$ \\
\hline \multirow[t]{2}{*}{ Stock return } & Raw data & 279 & -0.499 & -0.764 & 2,755 & -0.431 & -0.714 & $(0.089)$ & $(0.028)$ \\
\hline & Ind. adjusted & 278 & -0.572 & -0.627 & 2,757 & -0.444 & -0.472 & $(0.003)$ & $(0.000)$ \\
\hline
\end{tabular}




\section{Table IX. Regressions of Indirect Bankruptcy Costs on Industry Patent Competition}

The sample contains all firms that went bankrupt and did not issue patents during the three years prior to bankruptcy. In panel A the dependent variable is the abnormal earnings during the three years prior to bankruptcy scaled by asset book value, based on Altman's (1984) method; and in Panel B the dependent variable is the cumulative stock return in the three years prior to bankruptcy. Earnings and returns appear at both raw data (the actual bankruptcy costs) and industry adjusted data, which is the difference between the actual cost and the industry median. The main independent variable, Pct Ap, is the average percentage of firms in the industry that file successful patent applications during a calendar year. The control variable are: size is the log of the market value of equity, calculated by the stock price times the number of shares outstanding; market-to-book ratio is equity market value divided by equity book value; and leverage is the book value of debt divided by the book value of assets; all measured as of three years prior to bankruptcy. The table shows regression coefficients and $p$-values, based on standard errors clustered by individual firms, computed over 1976-2005.

\begin{tabular}{|c|c|c|c|c|c|c|c|}
\hline \multicolumn{8}{|c|}{ Panel A: Abnormal earnings } \\
\hline Raw data & Intercept & Pct Ap & Size & Market-to-book & Leverage & \# Obs & R-square \\
\hline \multirow[t]{2}{*}{$\begin{array}{l}\text { Coefficient } \\
\text { P-value }\end{array}$} & $\begin{array}{l}-0.14862 \\
(0.000)\end{array}$ & $\begin{array}{l}-0.25616 \\
(0.084)\end{array}$ & & & & 455 & 0.008 \\
\hline & $\begin{array}{l}-0.07187 \\
(0.349)\end{array}$ & $\begin{array}{l}-0.25499 \\
(0.082)\end{array}$ & $\begin{array}{l}-0.01334 \\
(0.054)\end{array}$ & $\begin{array}{l}-0.00593 \\
(0.544)\end{array}$ & $\begin{array}{l}0.20361 \\
(0.004)\end{array}$ & 455 & 0.042 \\
\hline \multicolumn{8}{|l|}{ Ind. adjusted } \\
\hline \multirow[t]{2}{*}{$\begin{array}{l}\text { Coefficient } \\
\text { P-value }\end{array}$} & $\begin{array}{l}-0.11576 \\
(0.000)\end{array}$ & $\begin{array}{l}-0.18377 \\
(0.156)\end{array}$ & & & & 455 & 0.005 \\
\hline & $\begin{array}{l}-0.09099 \\
(0.209)\end{array}$ & $\begin{array}{l}-0.17878 \\
(0.174)\end{array}$ & $\begin{array}{l}-0.00693 \\
(0.293)\end{array}$ & $\begin{array}{l}-0.00202 \\
(0.851)\end{array}$ & $\begin{array}{l}0.14849 \\
(0.012)\end{array}$ & 455 & 0.024 \\
\hline \multicolumn{8}{|c|}{ Panel B: Stock return } \\
\hline Raw data & Intercept & Pct Ap & Size & Market-to-book & Leverage & \# Obs & R-square \\
\hline \multirow[t]{2}{*}{$\begin{array}{l}\text { Coefficient } \\
\text { P-value }\end{array}$} & $\begin{array}{l}-0.35846 \\
(0.000)\end{array}$ & $\begin{array}{l}-0.59777 \\
(0.000)\end{array}$ & & & & 2,861 & 0.007 \\
\hline & $\begin{array}{l}0.45942 \\
(0.000)\end{array}$ & $\begin{array}{l}-0.48812 \\
(0.000)\end{array}$ & $\begin{array}{l}-0.06697 \\
(0.000)\end{array}$ & $\begin{array}{l}-0.05107 \\
(0.000)\end{array}$ & $\begin{array}{l}-0.11405 \\
(0.041)\end{array}$ & 2,861 & 0.077 \\
\hline \multicolumn{8}{|l|}{ Ind. adjusted } \\
\hline \multirow[t]{2}{*}{$\begin{array}{l}\text { Coefficient } \\
\text { P-value }\end{array}$} & $\begin{array}{l}-0.37189 \\
(0.000)\end{array}$ & $\begin{array}{l}-0.46721 \\
(0.000)\end{array}$ & & & & 2,828 & 0.005 \\
\hline & $\begin{array}{l}0.14565 \\
(0.102)\end{array}$ & $\begin{array}{l}-0.42313 \\
(0.001)\end{array}$ & $\begin{array}{l}-0.04156 \\
(0.000)\end{array}$ & $\begin{array}{l}-0.02589 \\
(0.000)\end{array}$ & $\begin{array}{l}-0.15606 \\
(0.003)\end{array}$ & 2,828 & 0.033 \\
\hline
\end{tabular}

